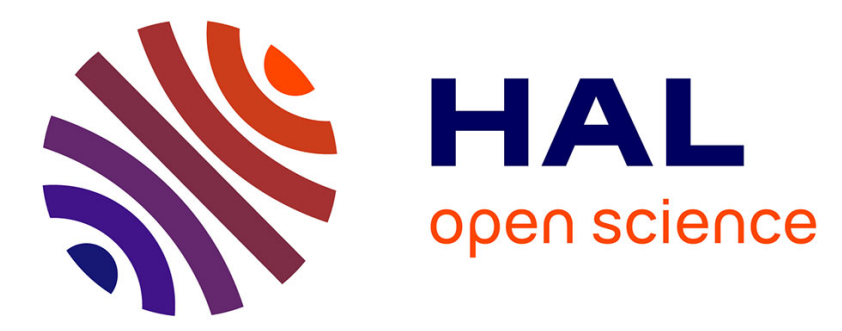

\title{
Coupling nickel chemical speciation and isotope ratios to decipher nickel dynamics in the Rinorea cf. bengalensis-soil system in Malaysian Borneo
}

I. Zelano, C. Cloquet, A. van Der Ent, G. Echevarria, R. Gley, G. Landrot, S. Pollastri, F. Fraysse, Emmanuelle Montargès-Pelletier

\section{To cite this version:}

I. Zelano, C. Cloquet, A. van Der Ent, G. Echevarria, R. Gley, et al.. Coupling nickel chemical speciation and isotope ratios to decipher nickel dynamics in the Rinorea cf. bengalensis-soil system in Malaysian Borneo. Plant and Soil, 2020, 10.1007/s11104-020-04541-0 . hal-02932912

\section{HAL Id: hal-02932912 https://hal.science/hal-02932912}

Submitted on 16 Nov 2020

HAL is a multi-disciplinary open access archive for the deposit and dissemination of scientific research documents, whether they are published or not. The documents may come from teaching and research institutions in France or abroad, or from public or private research centers.
L'archive ouverte pluridisciplinaire HAL, est destinée au dépôt et à la diffusion de documents scientifiques de niveau recherche, publiés ou non, émanant des établissements d'enseignement et de recherche français ou étrangers, des laboratoires publics ou privés. 
1 Coupling nickel chemical speciation and isotope ratios to decipher nickel dynamics in 2 the Rinorea cf. bengalensis-soil system in Malaysian Borneo

3

$4 \quad{ }^{1,2^{*}}$ Zelano, I.O., ${ }^{1}$ Cloquet, C., ${ }^{3}$ van der Ent A., ${ }^{4}$ Echevarria, G., ${ }^{2}$ Gley R., ${ }^{5}$ Landrot G., ${ }^{6}$ Pollastri S., ${ }^{2}$ Fraysse F., $5 \quad{ }^{2}$ Montargès-Pelletier, E.

$6 \quad{ }^{1}$ CRPG, UMR 7358, CNRS Université de Lorraine, 15 rue Notre-Dame-des-Pauvres, BP20, 54501, Vandœuvre7 lès-Nancy, France.

8 2LIEC, UMR 7360, CNRS Université de Lorraine, 15 avenue du Charmois, 54500, Vandœuvre- lès-Nancy, 9 France.

$10 \quad{ }^{3}$ Sustainable Minerals Institute, The University of Queensland, St Lucia, QLD 4072, Australia

$11{ }^{4}$ LSE, UMR 1120 INRA Université de Lorraine, 2 avenue de la Forêt de Haye, 54500 Vandœuvre-lès-Nancy, 12 France.

13 5ynchrotron SOLEIL, CEA CNRS, l’Orme des Merisiers, Saint Aubin BP 48, 91192 Gif sur Yvette Cedex, 14 France.

$15{ }^{6}$ CERIC - ERIC, Strada Statale 14, Basovizza, 34149 Trieste, Italia

*correspondence: isabella.zelano@unil.ch

\section{Abstract}

Aims. Rinorea cf. bengalensis is a Ni hyperaccumulator which occurs in Sabah (Malaysia), on Borneo Island, that is able to accumulate considerable amounts of $\mathrm{Ni}$ and influences the Ni cycle in surface soil layers, both in terms of Ni concentration and Ni isotopic composition. In this study, the biogeochemical processes underpinning $\mathrm{Ni}$ isotopic fractionation in the soil-plant system and the mechanisms regulating $\mathrm{Ni}$ homeostasis in $R$. cf. bengalensis plants were elucidated.

Methods. Two specimens of $R$. cf. bengalensis of different ages and associated surface soils were collected from ultramafic soils in Sabah. Soil mineralogy, Ni concentrations, speciation and isotopic signatures were subsequently determined in plant and soil samples.

Results. Nickel in $R$. cf. bengalensis leaves is mainly complexed with citrate. Soil Ni available fractions have different $\delta^{60} \mathrm{Ni}$ values depending on the Ni bearing phases. Rinorea $\mathrm{cf}$. bengalensis specimens take up lighter Ni isotopes and a pronounced isotopic fractionation within the plant is observed, especially in the young specimen. Conclusions. The results suggest that the observed fractionation in the young plant can be attributable to kinetic effects (lighter isotopes move faster), which become less evident in the older specimen, as Ni is redistributed and homogenized through phloem loading and unloading processes. 


\section{Introduction}

Ultramafic rocks are mantle rocks characterized by a specific composition with low silica, high contents of mafic minerals ( $\mathrm{Fe}$ and $\mathrm{Mg}$ oxides). Soils derived from the alteration of ultramafic rocks pose edaphic stresses for vegetation, including a low $\mathrm{Ca} / \mathrm{Mg}$ ratio, lack of essential nutrients such $\mathrm{N}, \mathrm{P}$, and $\mathrm{K}$, and a high concentrations of Mn, Ni, Cr and Co (Whittaker 1954; Bonifacio et al. 1997; Becquer et al. 2006). These soils are known for their hosting adapted vegetation, which includes the occurrence of hyperaccumulator plants that can achieve extraordinary levels of metal accumulation due to enhanced uptake and translocation mechanisms from the roots to the shoots (Baker, 1981). On ultramafic soils developed from serpentinized ultramafic rocks (which represent the most important terrestrial Ni reservoirs), numerous Ni hyperaccumulator plant species have been reported over the past 40 years (Reeves et al. 2018a). Hyperaccumulators can attain exceptionally high concentrations of $\mathrm{Ni}$ in their living tissues, with up to several weight percent $\mathrm{Ni}$ (e.g. $25 \mathrm{Wt} \%$ in latex or $16 \mathrm{Wt} \%$ in phloem sap) (Jaffre et al. 1976; Baker and Brooks 1988; Reeves 2003; van der Ent et al. 2013; Mesjasz-Przybylowicz et al. 2015; Reeves et al. 2018b; Jaffré et al. 2018). Nickel hyperaccumulator plants are known to transfer most of the $\mathrm{Ni}$ into their aerial parts (shoots) of the plant, instead of using root sequestration for metal detoxification (Baker, 1981). Via leaf litter deposition, hyperaccumulators can increase $\mathrm{Ni}$ concentrations of the soil in a surface area surrounding the plant (Boyd and Martens 1998). In tropical Southeast Asia, Rinorea cf. bengalensis (Violaceae) is one of more than 40 different Ni hyperaccumulator species identified from the Malaysian state of Sabah on Borneo Island (van der Ent et al. 2018b; 2019a). Rinorea cf. bengalensis is a large tree (up to 25m tall) that contain up to $4.77 \mathrm{~kg}$ of $\mathrm{Ni}$ (van der Ent and Mulligan 2015). Substantial Ni enrichment under the canopy of $R$. cf. bengalensis has been reported due to the degradation of leaf litter (van der Ent et al. 2015). However, it is still an open question to what extent $\mathrm{Ni}$ is recycled in the natural habitat of $R$. cf. bengalensis through Ni uptake, leaf shedding, re-uptake of $\mathrm{Ni}$ from decomposed leaf litter, and the Ni release in surface soil (Nkrumah et al. 2019b, d).

The interest toward Ni cycling at the Earth's surface has rapidly increased during the last decades but only a few scientific studies have been published proposing the use of stable Ni isotopes to elucidate the biogeochemical cycle of Ni in the upper soil horizons and surface waters (Elliott and Steele 2017). The degree of Ni isotope fractionation between the different surface compartments are a practical approach to identify and characterise the $\mathrm{Ni}$ biogeochemical processes. In order to better understand $\mathrm{Ni}$ isotopic fractionation on a larger scale, in 
catchments or soil-plant systems, the processes that fractionate $\mathrm{Ni}$ isotopes at the molecular scale need to be elucidated. Recent studies contributed to this understanding by showing $\mathrm{Ni}$ isotopic fractionation due to sorption onto mineral phases under laboratory controlled conditions (Wasylenki et al. 2015; Wang and Wasylenki 2017; Gueguen et al. 2018; Spivak-Birndorf et al. 2018), and due to complexation with organic acids relevant for the soil-plant system (Zelano et al. 2018). Nickel is involved in various biological reactions that might be implicated in isotopic fractionation (Cameron et al. 2009) but, to date, only few works have been focused on the impact of hyperaccumulator plant homeostasis on the Ni isotopic signature in surface soils (Deng et al. 2014; Estrade et al. 2015; Zelano et al. 2018; Ratié et al. 2019). However, isotopic fractionation of metals has been observed in higher plants and has been interpreted as a consequence of physiological processes involved in maintaining homeostasis, especially with regard to Fe (Guelke and von Blanckenburg 2007), Zn (Weiss et al. 2004; Tang et al. 2012, 2016; Deng et al. 2014; Caldelas and Weiss 2017), Cd (Imseng et al. 2018, 2019) and Cu (Jouvin et al. 2012). For example, in the case of $\mathrm{Zn}$, the preferential uptake at root level of heavier or lighter $\mathrm{Zn}$ isotopes has been associated with the presence of high- and low-affinity transport systems, respectively (Weiss et al. 2004; Caldelas and Weiss 2017). The type of transport system is dependent on the bioavailability of the metal, e.g. a high level of available $\mathrm{Zn}$ favours lighter isotopes uptake through low affinity transports, while a lower availability of the metal induces uptake of heavy isotopes through high affinity transporters (Tang et al. 2016). For $\mathrm{Zn}$, it has been suggested that further fractionation from roots to higher parts of the plant can take place during the xylem loading process and subsequent transportation (Tang et al. 2016).

In the case of $\mathrm{Ni}$, the physiological mechanisms regulating metal homeostasis are still largely unknown (Deng et al., 2014), but few studies posit that Ni sorption and translocation are regulated by low-affinity transport systems, and no high-affinity transport systems have been discovered hitherto in higher plants (Cataldo et al. 1978; Deng et al. 2014, 2019). Studying Ni isotopic fractionation and the homeostasis of the hyperaccumulator Alyssum murale grown in controlled hydroponic conditions, a preferential sorption of lighter isotopes from solution was observed $\left(\Delta^{60} \mathrm{Ni}_{\text {plant-solution }}=-0.9\right.$ to $-0.63 \%$ ) (Deng et al. 2014). It is still unclear, however, how and at which stage $\mathrm{Ni}$ isotopic fractionation exactly takes place. Studying plants collected in the temperate ultramafic area of Albania, Estrade et al. (2015) reported an enrichment in heavier isotopes of $\mathrm{Ni}$ in the plants compared to the bulk soil, $\Delta^{60} \mathrm{Ni}_{\text {whole plant-soil }}$ up to $0.40 \%$. Nevertheless, the $\mathrm{Ni}$ taken up by plants was lighter than the bioavailable Ni, extracted by diethylenetriaminepentaacetic acid (DTPA), and the difference $\Delta^{60} \mathrm{Ni}_{\text {available-rhizo soil }}$ was up to $0.89 \%$. This result suggests that hyperaccumulating plants take up lighter isotopes from the heavier bioavailable 
not report on any significant $\mathrm{Ni}$ isotopic fractionation neither during $\mathrm{Ni}$ uptake, nor during $\mathrm{Ni}$ translocation within the plants (Ratié et al. 2019). In our previous work, we have studied the remobilization of Ni by simulating the effect of leaf litter degradation of $A$. murale and $R$. cf. bengalensis. Obtained results showed that, in the case of $R$. cf. bengalensis, depending on the entity of the fractionation factor between roots and leaves, $\mathrm{Ni}$ recycling can result in a lighter isotope input into the surface soil (Zelano et al. 2018). Nickel hyperaccumulators, therefore, are responsible not only for "phyto-enrichment" of Ni concentration in surface soil, but they can also influence its isotopic composition. However, a clear mechanistic understanding of the observed $\mathrm{Ni}$ isotopic signatures in the soil-plant system and the links with the processes responsible for $\mathrm{Ni}$ isotopic fractionation have not been attained thus far. Only few publications have attempted to decipher the metal dynamics in the soil-rootshoot continuum by combining stable isotope tool and speciation data (Aucour et al. 2015, 2017). In this work, we developed an analytical strategy to follow $\mathrm{Ni}$ transfer from soil to plant shoots, considering the soil characteristics and the vertical distribution of $\mathrm{Ni}$ in the different horizons. Furthermore, in order to better understand the dynamics of $\mathrm{Ni}$ during the growth of a woody tropical hyperaccumulator tree, we investigated two differently aged plants. As such, this study focuses on two related soil-plant systems of $R$. cf. bengalensis naturally occurring on ultramafic soils, in the tropical rainforest of Kinabalu Park (Sabah, Borneo Island, Malaysia) (van der Ent and Mulligan 2015; van der Ent et al. 2015, 2018c; 2020). Two differently sized/aged

107 plants were sampled on two distinct soils having two different stages of pedogenesis. On the basis of $\mathrm{Ni}$ concentrations, Ni speciation and $\delta^{60} \mathrm{Ni}$ in soils and plants, first results on the Ni dynamics in the soil-plant system are provided and interpreted.

\section{$110 \quad$ Materials and methods}

111 All reagents were prepared using ultrapure water $(18.2 \mathrm{M} \Omega \mathrm{cm})$. Nitric and hydrochloric acids were of supra112 pure grade. Standard solutions were supplied by TechLab $\left(1000 \mu \mathrm{g} \mathrm{mL}^{-1}\right.$, in a $\left.2-5 \% \mathrm{HNO}_{3}\right)$.

\section{Plant material and soil collection}

115 Two individuals of $R$. cf. bengalensis were sampled in the native equatorial rainforest of Sabah, (Borneo Island,

116 Malaysia). The plants naturally developed on soils derived from serpentinized and non-serpentinized ultramafic 117 bedrock (for a detailed overview of the characteristics of the local soils, see van der Ent et al. 2018a; 2019b). The

118 first specimen, $\mathrm{R}_{150}$, measuring $150 \mathrm{~cm}$ high, was collected on a deeply weathered Ferralsol near Serinsim 119 (Nkrumah et al. 2018). The other individual, $\mathrm{R}_{600}$, is a tree of approximatively $6 \mathrm{~m}$ tall, and was collected near 
Lompoyou Hill, on an eroded hypermagnesian Cambisol on strongly serpentinized bedrock (Nkrumah et al. 2018; van der Ent et al. 2018a). According to a recent study (Nkrumah et al. 2019a,b), the $\mathrm{R}_{150}$ and $\mathrm{R}_{600}$ trees are estimated to be less than 1 year and about 3 years old, respectively. Although such trees are common in this area of the world, trees of different age were only found in distinct areas during our one-week campaign. This study is, therefore, focused on two trees of different age, respectively grown on a Ferralsol and on a Cambisol.

The $\mathrm{R}_{150}$ plant was harvested in its entirety and was subsequently divided into roots, trunk (later subdivided in bark and wood samples) and leaves. For $\mathrm{R}_{600}$, multiple leaf and bark samples were collected along the entire height of the plant, from 1-6 m. Two phloem tissue samples were extracted by stripping the inner bark from the wood core at $5 \mathrm{~cm}$ under and $5 \mathrm{~m}$ above soil level. In the young tree, the phloem tissue is thin and nearly impossible to sample (van der Ent and Mulligan 2015), therefore samples were collected only for $\mathrm{R}_{600}$. Two root samples, considered to be surface roots, were also collected at about $5 \mathrm{~cm}$ and $15 \mathrm{~cm}$ under soil level. Deeper root samples could not be collected.

The surface soils, between $0 \mathrm{~cm}$ and $15 \mathrm{~cm}$ depth, were collected at the base of $\mathrm{R}_{150}$ and $\mathrm{R}_{600}$ and referred to as $\mathrm{SR}_{150} \mathrm{H} 1$ (0-5 cm horizon), $\mathrm{SR}_{150} \mathrm{H} 2$ (5-15 cm horizon), and $\mathrm{SR}_{600} \mathrm{H} 1$ (0-5 cm horizon), $\mathrm{SR}_{600} \mathrm{H} 2(5-10 \mathrm{~cm}$ horizon) and $\mathrm{SR}_{600} \mathrm{H} 3$ (10-15 cm horizon) respectively. About $500 \mathrm{~g}$ for each sample were collected. Several rain forest species, including $R$. cf. bengalensis, are very shallow rooting and most of the nutrient cycling happens in the top layer of the soil (Vitousek 1984; Vitousek and Sanford 1986), so only superficial soil horizons were collected. Soils and plant samples were air-dried immediately after field collection, at temperature below $40^{\circ} \mathrm{C}$. This preparation mode was selected due to the sampling conditions and the sampling location was not compatible with the use of liquid nitrogen to preserve biological samples in situ. This mode of preparation is not usually recommended for XAS measurements, and the drying step may have influenced the chemical speciation of $\mathrm{Ni}$, replacing water molecules by other ligands. The breaking of cell walls and membranes during the drying

144 could have induced the dissociation of Ni complexes with low stability. However, XAS results obtained on 145 plants show that the Ni speciation was not drastically modified by drying and the results are consistent with 146 published data (van der Ent et al. 2017).

148 Due to their apparent difference in particle size distribution, soils were sieved to compare similar size fractions. 149 Each soil sample was, then, subdivided in two equivalent parts; one was kept and referred to as 'bulk sample', 
whereas the second part was sieved into four fractions, i.e. $>1.5 \mathrm{~mm} ; 1.5 \mathrm{~mm}-250 \mu \mathrm{m} ; 250-50 \mu \mathrm{m}$ and $<50 \mu \mathrm{m}$

\section{Element concentration}

153 All soil and plant samples were dried in a dehydrating oven at $110^{\circ} \mathrm{C}$ overnight, and manually ground using an 154 agate mortar. About 50-70 mg of ground plant material was weighed in Savilex® beakers and left overnight in $1553-5 \mathrm{~mL}$ of concentrated $(70 \%) \mathrm{HNO}_{3}$ at room temperature. Samples were, then, heated to $140^{\circ} \mathrm{C}$ on a hot plate to 156 complete the acid digestion. When necessary, a second digestion step was performed, using $3 \mathrm{~mL}$ of Aqua Regia 157 and $1-2 \mathrm{ml}$ of $\mathrm{HF}(32 \%)$ to allow for complete sample dissolution. Solutions were finally dried at $110^{\circ} \mathrm{C}$, 158 recovered with $0.3 \mathrm{M} \mathrm{HNO}_{3}$ and measured with Inductively Coupled Plasma Mass Spectrometer (ICP-MS 159 Quadrupole, X-Series Thermo Fisher Scientific).

Major and trace elements in soil samples were analysed by Service d'Analyse des Roches et des Minéraux

162 (SARM), at Centre de Recherches Pétrographiques et Géochimiques, Nancy, France. The content of organic carbon in soils was measured using the EMIA-Analyser Carbon/Sulfur supplied by HORIBA, after

164 decarbonation with $\mathrm{HCl}$ and filtration.

To estimate the available Ni concentration in soil samples, an aliquot of bulk soil was suspended in ultra-pure water for $24 \mathrm{~h}$, in triplicate, using $100 \mathrm{mg}$ soil and $40 \mathrm{~mL}$ of milli-Q water. The final suspension was centrifuged

168 for one hour at $52000 \mathrm{~g}$ and the resulting supernatant was filtered through $0.22 \mu \mathrm{m}$ with cellulose syringe filters.

169 Nickel concentration was measured in solution and, as an approximation, will be indicated hereafter as 'available

$170 \mathrm{Ni}$ '. Reported results of available Ni concentration correspond to the average values of experimental triplicates.

171 The bioavailable Ni pool in soils is operationally determined by chemical extraction using organic ligands, e.g.

172 DTPA (Echevarria et al. 2006). By performing, however, a water extraction we exclude any potential isotopic 173 fractionation arising from the Ni-ligand complex formation.

175 The cation exchange capacity (CEC) of the bulk soils was determined using cobalt hexammine. Briefly, $30 \mathrm{~mL}$ 176 of $0.05 \mathrm{~N}$ hexammine cobalt(III) chloride were added to $1 \mathrm{~g}$ of dry soil, shaken for two hours at $30^{\circ} \mathrm{C}$ and centrifuged at $52000 \mathrm{~g}$. Supernatants were filtered through $0.22 \mu \mathrm{m}$ and the residual concentration of hexammine analysed with UV spectrometry. This makes possible to determine the total CEC of the soil. Furthermore, 


\section{Nickel isotope measurements}

182 Prior to $\mathrm{Ni}$ isotopic measurement, a two-step chromatography separation was performed to remove sample 183 matrix. The reported procedure is based on a previously developed protocol (Cameron et al. 2009; Gueguen et al.

184 2013) and modified as described by Estrade et al. (2015) and Deng et al. (2014). Briefly, soil and plant samples 185 were digested, as described above, to determine, Ni content. Depending on the measured Ni concentration 186 (verified after digestion using a Q-ICP-MS X series 2 Thermo-Scientific), a known volume of dissolved sample 187 was evaporated to give a mass of $\mathrm{Ni}$ between 1 and $2 \mu \mathrm{g}$. After evaporation, the residue was dissolved again in 2 $188 \mathrm{~mL}$ of $3 \mathrm{M} \mathrm{HNO}_{3}$. In order to correct for any isotope composition variation potentially induced by the chemistry 189 process, and for an instrumental mass bias, the technique of a double-spike addition was adopted. For that, a 190 double-spike solution containing an equal amount of ${ }^{61} \mathrm{Ni}$ and ${ }^{62} \mathrm{Ni}$ isotopes was added to samples. The volume 191 of double-spike solution to add was adapted for each sample to obtain a spike/sample ratio of 1.15 . The mix was

192 left equilibrating overnight, evaporated on a hot plate at $110^{\circ} \mathrm{C}$ and dissolved in $1 \mathrm{~mL}$ of $6 \mathrm{M} \mathrm{HCl}$. Solution was, 193 then, passed on the first chromatographic column filled up with $2 \mathrm{ml}$ of the anion-exchange resin $A G \AA 1-X 8$ and 194 recovered. The resin, which is in chloride form, is able to retain $\mathrm{Fe}$ and $\mathrm{Zn}$ present in the sample matrix, while Ni 195 is eluted with the solution. Additional $15 \mathrm{~mL}$ of $6 \mathrm{M} \mathrm{HCl}$ were passed through the column to recover all Ni. The 196 final volume was successively evaporated on a hot plate at $110^{\circ} \mathrm{C}$ and dissolved again in $1 \mathrm{~mL} \mathrm{HCl} 1 \mathrm{M}$. The 197 second chromatographic separation to complete the sample purification is based on the use of a Ni specific resin, 198 supplied by Triskem Inc., France. The used resin is able to retain Ni through chelation with dimethylglyoxime at $199 \mathrm{pH}$ value $8-9$. Before the second chromatographic separation, $0.2 \mathrm{~mL}$ of ammonium citrate $\left(\left(\mathrm{NH}_{4}\right)_{6} \mathrm{C}_{6} \mathrm{H}_{6} \mathrm{O}_{7}\right)$ 200 were added to the samples, the $\mathrm{pH}$ was adjusted at 8-9 with 100-150 $\mu \mathrm{L}$ of ammonia, and samples were left 201 overnight for equilibration. Solution was loaded on the column and Ni retained by the resin was successively recovered by $4 \mathrm{~mL}$ of $3 \mathrm{M} \mathrm{HNO}_{3}$ and put to evaporate on a hot plat at $110^{\circ} \mathrm{C}$. To eliminate any potential residue, acid digestion with aqua regia were performed, before recovery the sample with $0.3 \mathrm{M} \mathrm{HNO}_{3}$ for measurement. Procedural blanks were prepared in each sample batch, resulting in $0.058-0.256 \mathrm{nmol}$ of Ni content that has a maximum value of $1.5 \%$ of the total $\mathrm{Ni}$, and a corresponding negligible influence on reported isotopic values, within uncertainties. 
The solutions were measured by Multi-Collector Inductively Coupled Plasma Mass Spectrometer (MC-ICP-MS, Neptune plus, Thermo Scientific) in medium resolution mode and using an Apex HF desolvation introduction system in a $0.3 \mathrm{M} \mathrm{HNO}_{3}$ media. Ni masses $(58,60,61,62)$ were measured simultaneously as well as $\mathrm{Cu}$ isotopes and one Fe isotope at masses 63,65 and 57 respectively. The ${ }^{57} \mathrm{Fe}$ intensity was monitored continuously to

212 correct for any ${ }^{58} \mathrm{Fe}$ contribution to ${ }^{58} \mathrm{Ni}$. The correction is effective only for a signal lower than $10 \mathrm{mV}$. When 213 the signal was higher than $10 \mathrm{mV}$, samples were processed and eluted again through the first column. A standard 214 bracketing method was used during sample measurements and $\delta^{60} \mathrm{Ni}$ in samples were normalized to NIST-986. 215 Sample $\delta^{60} \mathrm{Ni}$ values were calculated as:

The analytical reproducibility was monitored by processing and measuring a Ni ICP-MS standard solution for each measurement session. Since no value exist for this solution, the standard subjected and not-subjected to the entire sample preparation procedure was measured and compare to itself, in order to control for isotopes composition modification during the process. The obtained average value was $\delta^{60} \mathrm{Ni}=-0.11 \pm 0.05 \%$ ( $2 \sigma$, $\mathrm{n}=25$ ). The reference material BHVO-2 was processed and measured ten times in different measurement sessions, obtaining $\delta^{60} \mathrm{Ni}=0.05 \pm 0.04 \%(2 \sigma)$, in agreement with published data (Gall et al. 2013; Gueguen et al. 2013; Estrade et al. 2015; Ratié et al. 2015). Estimated recovery from the measured intensities is always higher than $90 \%$. However, recovery is not a crucial parameter as the double spike addition technique was used. In addition, in order to have a matrix match reference for plant samples, the Oak Leaves reference material V464 from the French National Institute for Agricultural Research (INRA) was also digested, purified and measured. The value obtained for this material is $\delta^{60} \mathrm{Ni}=-0.02 \pm 0.05 \%$ o $(2 \sigma, \mathrm{N}=6)$.

232 All samples were measured three times. The soil-water suspension samples to determine available Ni were prepared in triplicate. For those samples, the reported $\delta^{60} \mathrm{Ni}$ values correspond to the average $X$ of experimental

234 triplicates $x_{m}$. The associated standard error $(2 \sigma)$ is calculated as: 
where $s d$ is the standard deviation of the sample mean, and $\mathrm{N}$ is the number of samples.

240 For bulk soil and plant material samples, no experimental triplicates are available and the reported $2 \sigma$ represent

241 the analytical error deriving from three measurements of the sample. The $2 \sigma=0.05 \%$ obtained for the Ni ICP-

242 MS standard (digested and measured 25 times) was applied to all sample results presenting analytical $2432 \sigma<0.05 \%$.

245 The Ni isotopic fractionation between two samples $\mathrm{A}$ and $\mathrm{B}, \Delta{ }^{60} \mathrm{Ni}_{\mathrm{A}-\mathrm{B}}$, was calculated as the difference 246 between the isotopic signatures measured in A and B, as reported below:

$248 \quad \Delta^{60} \mathrm{Ni}_{\mathrm{A}-\mathrm{B}}=\delta^{60} N i_{A}-\delta^{60} N i^{2+}{ }_{\mathrm{B}}$

250 The standard deviation $\sigma$ associated to $\Delta^{60} \mathrm{Ni}$ includes the error propagation and was calculated as:

\section{Soil mineralogical composition}

254 The mineralogical composition of the samples was determined by X-ray diffraction (XRD, Bruker D8 Advance) with an X-ray tube producing Co $\mathrm{K} \alpha$ radiation (1.78886 $\AA$ ) operated at $35 \mathrm{kV}$ and $45 \mathrm{~mA}$. The XRD patterns were obtained by scanning crushed powders of the sieved fractions and of the bulk soil, from $3^{\circ}$ to $64^{\circ} 2 \theta$ with a $0.035^{\circ} 2 \theta$ step and with a $3 \mathrm{~s}$ counting time per step. The diffracted signal was measured using a LynxEye detector with an energy discrimination window adjusted to minimize the high fluorescence background signal coming from Fe to improve the peak-to-background ratio.

Soil mineralogy was also investigated with electron microscopy, and transmission electron images were obtained with a Philips CM20 transmission electron microscope (TEM), operating at $200 \mathrm{kV}$, coupled to an EnergyDispersive X-ray Spectrometer (EDXS). For TEM imaging and microanalysis, a few milligrams of sample were re-suspended in ethanol using ultrasonication (10 $\mathrm{min})$ and a drop of suspension was evaporated on a carboncoated copper grid. The EDX spectra were obtained in nanoprobe mode $(20-30 \mathrm{~nm})$ using a counting time of 40-70 seconds. 
268 X-ray absorption spectroscopy (XAS) experiments were performed at two beamlines, in fluorescence mode at 269 the SAMBA beamline (SOLEIL synchrotron, France), and in transmission mode at the XAFS beamline 270 (ELETTRA synchrotron, Italy). In both cases, Ni K-edge X-ray absorption spectra (both in the XANES and 271 EXAFS regions) were recorded at low temperature (using a liquid He cryostat $25 \mathrm{~K}$ and liquid $\mathrm{N}_{2}$ cryostat, $77 \mathrm{~K}$ respectively) with a $\mathrm{Si}(111)$ double crystal monochromator. A Ni foil was positioned after the sample and collected simultaneously to each spectrum in order to have perfect energy calibration; the first inflection point of metal Ni spectrum was calibrated at $8333 \mathrm{eV}$. Soil samples were scanned at SAMBA in fly scan mode from 8000 to 9500 at velocity of $5 \mathrm{eV} / \mathrm{s}$, resulting in energy step of $0.5 \mathrm{eV}$, using an X-ray fluorescence detector (VORTEX, Hitachi). For each soil sample, between 22 and 35 spectra were recorded. Dried leaf samples were measured at the XAFS beamline in transmission detection mode, with three scans recorded in a step by step mode, with $5 \mathrm{eV}$ steps for the first $200 \mathrm{eV}, 0.2 \mathrm{eV}$ for the XANES range and with a k-constant step of $0.03\left(\AA^{-1}\right)$ in the EXAFS range. In all cases, the samples were ground and pelletized before the XAS measurements. Reference spectra were obtained on the SAMBA and XAFS beamlines from previous sessions, under the same acquisition conditions. These standards included $\mathrm{Ni}$ aqueous solution with and without organic ligands, $\mathrm{Ni}$ incorporated into goethite, Ni sorbed onto phyllosilicate (charged and non-charged minerals), Ni sorbed onto calcite, Ni sorbed onto iron oxyhydroxide (goethite), and natural $\mathrm{Ni}$ containing minerals including chrysoprase, nimite, and $\mathrm{Ni}$ bearing serpentine (clay mineral).

The XANES and EXAFS data were reduced using standard normalization procedures performed with the ATHENA and ARTEMIS programmes (Ravel and Newville 2005). The spectra were background subtracted, and normalized. A spline function was fit through the absorption envelope and subtracted from each spectrum. To transform data from energy space $\mathrm{E}(\mathrm{eV})$ to wave vector space $\mathrm{k}\left(\AA^{-1}\right), \mathrm{E}_{0}$ edge energy was chosen in the higher part of the edge step, at $8343 \mathrm{eV}$. The resulting $\chi$ function was weighted by $\mathrm{k}^{3}$ to avoid oscillations damping at high $\chi$ values. The EXAFS signals obtained from plant and soil samples were fitted as linear combinations of the standard EXAFS spectra collected on solutions and solid samples. The number of components was set to a maximum of three on the basis of TEM and XRD observations. The fitting parameters were then selected on the basis of quality indicators $\left(\chi^{2}, r\right.$-factor and reduced $\left.\chi^{2}\right)$. Shell by shell fitting was also performed using theoretical scattering paths calculated from the unit cell structure of distinct Ni-bearing phases (Artemis code on the basis of FEFF6) (Ravel and Newville 2005; Rehr et al. 2010). 


\section{Results}

299

300

301

302

303

304

305

306

307

308

309

310

311

312

313

314

315

316

317

318

319

320

321

322

323

324

325

326

327

\section{Chemical and mineralogical composition of soils}

The elemental concentrations were determined in the different horizons of soils associated with plants, $\mathrm{SR}_{150}$ and $\mathrm{SR}_{600}$, for the bulk samples and for the size fractions i) $>1.5 \mathrm{~mm}$, ii) $250-50 \mu \mathrm{m}$, and iii) $<50 \mu \mathrm{m}$, of both $\mathrm{H} 1$ horizons (Table SI 1). The major element contents are typical for soils developed on ultramafic bedrock (van der Ent et al. 2018a). The Fe content is relatively high, especially in $\mathrm{SR}_{150}$, where it reaches up to 34 and $39.8 \%$ $\left(\mathrm{Fe}_{2} \mathrm{O}_{3} \%\right)$, while it ranges from 4.6 and $22.1 \%$ in $\mathrm{SR}_{600}$, with a clear increasing trend with depth in the latter case. The $\mathrm{Si}$ content is rather similar in the surface horizons of $\mathrm{SR}_{150}$ and $\mathrm{SR}_{600}$, with up to 28.9 and $29.2 \%\left(\mathrm{SiO}_{2}\right.$ \%) respectively. However, this content tends to increase with depth for $\mathrm{SR}_{600}$, reaching up to 36.9 and $35.4 \%$ in the $\mathrm{H} 2$ and $\mathrm{H} 3$ horizons respectively. The third major element discriminating the soils is $\mathrm{Mg}$, which reaches up to $1.6 \%(\mathrm{MgO} \%)$ in $\mathrm{SR}_{150}$ and which ranges between 10.9 and $13.4 \%$ in the $\mathrm{SR}_{600}$ soil horizons. Organic carbon is higher in $\mathrm{RS}_{600}(11.84 \%$ in $\mathrm{H} 1)$ than in $\mathrm{RS}_{150}(7.44 \%$ in $\mathrm{H} 1)$ and in both cases organic carbon decreases with depth. The trace elements are slightly higher in $\mathrm{SR}_{150}$ than in $\mathrm{SR}_{600}$. In general, no marked changes within the soil profile can be observed for all trace elements measured. These results are consistent with previously published data of ultramafic rhizosphere soils, collected in the same area in Sabah, that constitute the habitat of $R$. cf. bengalensis (van der Ent et al. 2015, 2017; 2020).

Nickel concentrations (Table 1) are higher in $\mathrm{SR}_{150}$ than in $\mathrm{SR}_{600}$, reaching $113 \mu \mathrm{mol} \mathrm{g} \mathrm{g}^{-1}$ and only $61 \mu \mathrm{mol} \mathrm{g}{ }^{-1}$, respectively. In both cases, Ni concentration remains rather constant in the different horizons, but decreases with soil size fraction (from fraction $>1.5 \mathrm{~mm}$ to fraction $<50 \mu \mathrm{m}$ ). Available Ni in bulk samples was estimated by measuring $\mathrm{Ni}$ concentration in the supernatant from soil-aqueous suspension. For $\mathrm{SR}_{150} \mathrm{H} 1$ and $-\mathrm{H} 2$, the concentration of available $\mathrm{Ni}$ is about $0.35 \mu \mathrm{mol} \mathrm{g}{ }^{-1}$, while it is $0.40 \mu \mathrm{mol} \mathrm{g}^{-1}$ in $\mathrm{SR}_{600} \mathrm{H} 1$ and decreases in $\mathrm{SR}_{600} \mathrm{H} 2$ and $\mathrm{SR}_{600} \mathrm{H} 3$ to $0.19 \mu \mathrm{mol} \mathrm{g}{ }^{-1}$ and $0.09 \mu \mathrm{mol} \mathrm{g}{ }^{-1}$, respectively.

The highest cationic exchange capacity (CEC) in both bulk soil samples (Table SI 2) is observed in the H1 horizons (54.6 mEq per $100 \mathrm{~g}$ and $22.7 \mathrm{mEq}$ per $100 \mathrm{~g}$ in $\mathrm{SR}_{600} \mathrm{H} 1$ and $\mathrm{SR}_{150} \mathrm{H} 1$, respectively). In both cases, $\mathrm{CEC}$ decreases with depth as a result of the decrease of organic matter. As a general trend, $\mathrm{SR}_{600}$ has a higher $\mathrm{CEC}$ than $\mathrm{SR}_{150}$ and the difference in CEC between the two soils, about $32 \mathrm{meq} 100 \mathrm{~g}^{-1}$, mainly derives from the higher concentration of exchangeable $\mathrm{Mg}$ that reaches $42.4 \mathrm{mEq}$ per $100 \mathrm{~g}$ in $\mathrm{SR}_{600} \mathrm{H} 1$, but only $5.8 \mathrm{mEq}$ per 

similar in both $\mathrm{H} 1$ horizons, but its relative contribution to total CEC is $6 \%$ in $\mathrm{SR}_{150}$ and is less than $1 \%$ in $\mathrm{SR}_{600}$. Moreover, it slightly increases in $\mathrm{SR}_{150} \mathrm{H} 2$, while it decreases in $\mathrm{SR}_{600} \mathrm{H} 2-\mathrm{H} 3$.

The mineralogy, as revealed by both XRD and TEM data, supports the discrimination of $\mathrm{SR}_{150}$ and $\mathrm{SR}_{600}$ soils

(Fig.1 and Fig. SI 1-2). SR 600 XRD patterns (in all horizons and size fractions) show the presence of

334 phyllosilicate phases, commonly encountered in ultramafic soils. The clay minerals are represented by chlorite, talc and $7 \AA$ minerals (i.e. serpentine and kaolinite) and are associated with other silicates such as quartz, feldspars and amphiboles, as well as Fe-oxyhydroxide (goethite). The mineralogy of $\mathrm{SR}_{600}$ relates to the presence of the serpentinized bedrock beneath and to a less advanced weathering of this soil. The XRD patterns have intense diffraction peaks from amphibole and chlorite minerals (Fig. SI 2). For the second soil $\mathrm{SR}_{150}$, quartz, talc and goethite diffraction lines dominate XRD patterns. Those patterns are all drastically different from those obtained for the $\mathrm{SR}_{600}$ samples, with a smaller number of crystalline phases (Fig. SI 1), and the presence of goethite is consistent with the higher Fe content in the $\mathrm{SR}_{150}$ soil samples. For both soils, $\mathrm{XRD}$ data do not reveal any variation in the different horizons and size fractions. The $\mathrm{XRD}$ analysis of the clay fraction of $\mathrm{SR}_{600}$ shows the predominance of chlorite minerals, and additional $7 \AA$ minerals (from the serpentine or kaolinite groups).

The XRD analysis is sensitive to crystalline phases only and soils are commonly constituted of poorly crystalline or amorphous phases. To enhance the mineralogical investigations, TEM images and combined spectra (EDX) were acquired on the fine fraction $(<50 \mu \mathrm{m})$ of the topsoil horizons from $\mathrm{SR}_{150}$ and $\mathrm{SR}_{600}$ (Figure 1). The TEM micrographs for $\mathrm{SR}_{150}$ reveal mainly talc and goethite particles. Associated EDX spectra show that in $\mathrm{SR}_{150} \mathrm{Ni}$ is mainly associated with Fe-oxyhydroxides, including goethite. In $\mathrm{SR}_{600}$, different types of clay minerals are observed, as well as several poorly defined phases. For $\mathrm{SR}_{150}$, goethite appears to be the predominant Fe-bearing phase, while for $\mathrm{SR}_{600}$, TEM analyses reveal the presence of amorphous Fe-oxyhydroxides, frequently containing $\mathrm{Ni}$ (shown by EDX analysis). In the latter sample, $\mathrm{Ni}$ was detected in most of the investigated particles, ranging from 0.3 to $0.9 \%$ (atomic percentage, EDX data) including silicate particles.

The XAS spectra and extracted EXAFS oscillations were used to determine the solid speciation of $\mathrm{Ni}$ in the soils 
that $\mathrm{Ni}$ has the same oxidation state (2+) and octahedral coordination. Some differences, however, can be observed in the XANES region and on EXAFS oscillations that are consistent with mineralogy results (TEM-

360 EDXS and XRD). Superimposition of XANES spectra reveals slight differences in the position of the main edge and of the first oscillation (Fig. SI.3). Differences were also noticed in the EXAFS oscillations and associated

362 Fourier transforms (Fig.2). Fourier transform curves (imaginary and magnitude parts) show that the slight 363 differences between these two spectra come from the nature and distribution of atoms in the $2^{\text {nd }}$ and further 364 coordination spheres (Fig.2). Shell by shell fitting shows that for both soil samples, six atoms of oxygen at 2.03$3652.1 \AA$ surround Ni atoms, and dominate the backscattering signal (Table 2).

367 Shell-by shell fitting (Table 2) also indicates the presence of Fe atoms at 3.07 and $3.54 \AA$ in the case of $\mathrm{SR}_{150}$, 368 supporting the hypothesis that a fraction of $\mathrm{Ni}$ is adsorbed onto Fe oxyhydroxides, or is inserted in the crystal lattice of Fe oxyhydroxides. This conclusion is consistent with the higher concentration of Fe (i.e. goethite) in this sample $\mathrm{SR}_{150}$ (See table SI 1). For $\mathrm{SR}_{600}$, FEFF fitting also shows the presence of low $\mathrm{Z}$ atoms at $3.26 \AA$, supporting the hypothesis that a part of $\mathrm{Ni}$ is incorporated in the silicate structure. This result is also correlated with the high proportion of phyllosilicates in sample $\mathrm{SR}_{600}$ (XRD and TEM data). Linear combination fitting

373 (Table 2) reveals matches with reference spectra in the samples $\mathrm{SR}_{600}$ and $\mathrm{SR}_{150}$ : Ni sorbed onto smectite (59\% 374 and $50 \%$ for $\mathrm{SR}_{600}$ and $\mathrm{SR}_{150}$ respectively), $\mathrm{Ni}$ sorbed onto goethite (16\% and $50 \%$ for $\mathrm{SR}_{600}$ and $\mathrm{SR}_{150}$ respectively, and $\mathrm{Ni}$ in serpentine $\left(26 \%\right.$ for $\left.\mathrm{SR}_{600}\right)$ (Fig. 2).

\section{Element concentrations and Ni chemical speciation in plant samples}

377 Multi-elemental analyses were performed on different plant material of $R_{150}$ and $R_{600}$ which conform with 378 concentrations ranges previously reported for $R$. cf. bengalensis (van der Ent et al. 2017; 2020). Results and 379 detailed discussion are provided in Supplementary Information Table SI 3-4 and associated notes. weight was $91.96 \mathrm{~g}$. The plant was then divided in leaf, root, bark and wood samples and, except for leaves, the quantification of their relative mass was difficult to achieve. However, an estimation of the relative mass of bark and wood was made, and on the basis of the corresponding $\mathrm{Ni}$ concentration, the total $\mathrm{Ni}$ content has been calculated to be $8018 \mu \mathrm{mol}$. The weighted average concentration in the whole plant was $87.20 \pm 70.65 \mu \mathrm{mol}$ of Ni per $g$ of plant. The weighted standard deviation has been calculated as reported in equation 5 : 
$387 \quad \mathrm{sd}_{\mathrm{w}}=\sqrt{\frac{\sum_{i=1}^{N} w i(x i-x m)^{2}}{\frac{(N-1) \sum_{i=1}^{N} w i}{N}}}$,

388 where wi is the weight for the ith observation, $N$ is the number of non-zero weights, and $x w$ is the weighted mean 389 of the observations.

391 In line with data previously published for $R$. cf. bengalensis (van der Ent et al. 2017; 2020), Ni concentrations

392 leaves are high, between $134 \mu \mathrm{mol} \mathrm{g}^{-1}$ and $221 \mu \mathrm{mol} \mathrm{g}^{-1}$ in $\mathrm{R}_{150}$ and, with the exception of leaves at $80 \mathrm{~cm}$ height,

393 Ni slightly decreases from the bottom to the top of the plant (Table 4). In contrast, no clear trend can be observed 394 in the bark samples where Ni concentrations range between $43 \mu \mathrm{mol} \mathrm{g}^{-1}$ and $98 \mu \mathrm{mol} \mathrm{g}{ }^{-1}$, decreasing from $20 \mathrm{~cm}$ 395 to $60 \mathrm{~cm}$ and increasing again from $60 \mathrm{~cm}$ to $90 \mathrm{~cm}$. Nickel concentrations in the wood samples have an 396 increasing trend from the bottom to the top, from $6.68 \mu \mathrm{mol} \mathrm{g}^{-1}$ to $70 \mu \mathrm{mol} \mathrm{g}^{-1}$. A different trend is observed in

$397 \mathrm{R}_{600}$, where Ni concentrations, both in leaf and bark samples, clearly decreases as a function of plant height: from $398522 \mu \mathrm{mol} \mathrm{g}^{-1}$ in older leaves at $2 \mathrm{~m}$, to $156 \mu \mathrm{mol} \mathrm{g}^{-1}$ in younger leaves at $6 \mathrm{~m}$, and Ni concentrations in bark at 399 the same height decreases from $133 \mu \mathrm{mol} \mathrm{g}^{-1}$ to $53 \mu \mathrm{mol} \mathrm{g}^{-1}$. Two root samples per plant were collected at about $4005 \mathrm{~cm}$ and $15 \mathrm{~cm}$ under the soil surface and $\mathrm{Ni}$ concentrations have similar range, $154 \mu \mathrm{mol} \mathrm{g}^{-1}$ and $81.7 \mu \mathrm{mol} \mathrm{g}$ 401 in $\mathrm{R}_{150}$, and $63.2 \mu \mathrm{mol} \mathrm{g}^{-1}$ and $111 \mu \mathrm{mol} \mathrm{g}^{-1}$ in $\mathrm{R}_{600}$.

402

403 Nickel chemical speciation in R. cf. bengalensis leaves was investigated (Fig. 3, Table 3) and the XAS spectra 404 are rather similar evidencing that $\mathrm{Ni}$ speciation is predominated by $\mathrm{Ni}$ complexed with low molecular weight 405 carboxylic acids (malate and citrate). These results are consistent with those previously reported (van der Ent et 406 al. 2017), and suggest that Ni chemical speciation was not drastically changed by the drying step. XAS spectra 407 could not reveal any differences of chemical speciation of $\mathrm{Ni}$ in the investigated $R$. cf. bengalensis specimen. 408 Linear combination fitting suggests the contribution of hydrated cations $\mathrm{Ni}^{2+}\left(\mathrm{H}_{2} \mathrm{O}\right)_{6}$ at $33 \%$ and $31 \%$ for $\mathrm{R}_{600}$ and $409 \mathrm{R}_{150}$ respectively, the presence of Ni-malate complexes at $41 \%$ and $42 \%$ for $\mathrm{R}_{600}$ and $\mathrm{R}_{150}$ respectively, and Ni410 citrate complexes at $26 \%$ and $27 \%$ for $\mathrm{R}_{600}$ and $\mathrm{R}_{150}$ respectively.

412 The chemical speciation of $\mathrm{Ni}$ in $R$. cf. bengalensis leaves supports the idea that $\mathrm{Ni}$ is not strongly chelated by 413 specific organic molecules and is not considered as a contaminant or as xenobiotic by the plants. The apparent 414 weakly bound state of Ni makes it readily mobile, and Ni might be not permanently stored within the leaves. 

mobile, whatever the age of the tree.

\section{Nickel isotopic composition in soils and plants}

419 The $\delta^{60} \mathrm{Ni}$ values in bulk soils $\left(\delta^{60} \mathrm{Ni}_{\text {bulk }}\right)$ and in the available fraction $\left(\delta^{60} \mathrm{Ni}_{\text {available }}\right)$ are shown in Table 1 . The bulk soil horizons of $\mathrm{SR}_{150}$ and $\mathrm{SR}_{600}$ have slightly different $\mathrm{Ni}$ isotopic signatures, $\delta^{60} \mathrm{Ni}_{\text {bulk_RS150_H1 }}=-$ $0.17 \pm 0.05 \%, \quad \delta^{60} \mathrm{Ni}_{\text {bulk_SR150_H2 }}=-0.16 \pm 0.05 \%, \quad$ and $\quad \delta^{60} \mathrm{Ni}_{\text {bulk_RS600_H1 }}=-0.01 \pm 0.05 \%$, $\delta^{60} \mathrm{Ni}_{\text {bulk_RS600_H2 }}=0.01 \pm 0.06 \%$, respectively. In both cases, $\delta^{60} \mathrm{Ni}$ does change neither with depth, nor in the $<50 \mu \mathrm{m}$ fractions of $\mathrm{H} 1$ compare to the bulk. The $\mathrm{SR}_{150} \mathrm{H} 1$ available $\mathrm{Ni}\left(\delta^{60} \mathrm{Ni}_{\text {available_RS150_H1 }}\right)$ is slightly enriched in lighter $\mathrm{Ni}$ isotopes in comparison with the corresponding bulk soil $\mathrm{SR}_{150}\left(\delta^{60} \mathrm{Ni}_{\text {available_RS150_H1 }}=-\right.$ $0.32 \pm 0.09 \%$ ), obtaining $\Delta^{60} \mathrm{Ni}_{\text {bulk-available_RS150_H1 }}=0.15 \pm 0.10 \%$. However, this result is not observed for the lower horizon $\mathrm{SR}_{150} \mathrm{H} 2$, where available $\mathrm{Ni}$ is similar to the bulk soil, $\delta^{60} \mathrm{Ni}_{\text {available } \mathrm{RS} 150 \mathrm{H} 2}=-0.14 \pm 0.05 \%$, and $\Delta^{60} \mathrm{Ni}_{\text {bulk-available_RS150_H2 }}=-0.02 \pm 0.07 \%$. On the contrary, $\mathrm{SR}_{600}$ available $\mathrm{Ni}$ has an enrichment in heavier $\mathrm{Ni}$ isotopes, increasing with soil depth, $\delta^{60} \mathrm{Ni}_{\text {available_RS600_H1 }}=0.32 \pm 0.05 \%, \delta^{60} \mathrm{Ni}_{\text {available_RS600_H2 }}=0.52 \pm 0.05 \%$ o and $\delta^{60} \mathrm{Ni}_{\text {available_RS600_H3 }}=0.62 \pm 0.05 \%$. The isotopic difference with the corresponding bulk soils were calculated as $\Delta^{60} \mathrm{Ni}_{\text {bulk-available_RS600_H1 }}=-0.33 \pm 0.06 \%$ and $\Delta^{60} \mathrm{Ni}_{\text {bulk-available_RS600_H2 }}=-0.51 \pm 0.07 \%$.

The $\mathrm{Ni}$ isotopic composition of the two $R$. cf. bengalensis specimens $\mathrm{R}_{150}$ and $\mathrm{R}_{600}$ are reported on Table 4 . The root samples from $\mathrm{R}_{150}$ plant at $-5 \mathrm{~cm}$ and $-15 \mathrm{~cm}$ under the surface level has $\delta^{60} \mathrm{Ni}_{\text {roots }}=-0.35 \pm 0.05 \%$ and $\delta^{60} \mathrm{Ni}_{\text {roots }}=-0.42 \pm 0.05 \%$, respectively. Similarly, the surface roots of $\mathrm{R}_{600}$ plant, both collected at -5 and $-15 \mathrm{~cm}$ under surface level, has negative values, $-0.58 \pm 0.05 \%$ and $-0.59 \pm 0.06 \%$ respectively (Table 4 ).

In the aerial parts, $\delta^{60} \mathrm{Ni}$ in leaves of $\mathrm{R}_{150}$ is between -0.66 and $-0.89 \%$, clearly showing a preferential translocation of light $\mathrm{Ni}$ isotopes from the roots to the leaves (Tables 4 and 5) and, among the leaves, from the bottom to the top, with the presence of lighter Ni isotopes in the younger apical leaves. Moreover, it can be seen from Fig. 4 that leaves, which constitute the Ni-enriched parts of the plants (table 4), have $\delta^{60} \mathrm{Ni}$ values lighter than the ligneous material, i.e. wood and bark. The wood and bark samples have relatively wide-ranging values. However, with the exception of the wood sample at $100 \mathrm{~cm}$, a preferential concentration of heavier $\mathrm{Ni}$ isotopes can be observed from the bottom to the top of the plant. The $\delta^{60} \mathrm{Ni}$ value of the whole plant $\mathrm{R}_{150}$ was estimated by calculating the weighted mean of the $\delta^{60} \mathrm{Ni}$ in the different parts of the plant, 
447 The $\delta^{60} \mathrm{Ni}$ values in $\mathrm{R}_{600}$ leaves range between $-0.19 \%$ and $-0.33 \%$, but no systematic variation is observed 448 between the basal and apical leaves, collected from 2 to $6 \mathrm{~m}$. Moreover, bark samples also have variable $\delta^{60} \mathrm{Ni}$ 449 values, from $-0.29 \%$ to $0.15 \%$, in some cases heavier and in others lighter than the leaves collected at the same 450 height, without any clear trend. The phloem tissue sample collected from beneath the bark at $-5 \mathrm{~cm}$ has a similar 451 isotopic composition than root collected at the same level, $\delta^{60} \mathrm{Ni}_{\text {phloem }}=-0.60 \pm 0.08 \%$. The phloem tissue at $5 \mathrm{~m}$ 452 high has, on the contrary, a heavier Ni isotopic composition $\left(\delta^{60} \mathrm{Ni}_{\text {phloem }}=-0.10 \pm 0.06 \%\right.$ ), than leaf and bark at 453 the same height, $\delta^{60} \mathrm{Ni}_{\text {leaf }}=-0.30 \pm 0.05 \%$ and $\delta^{60} \mathrm{Ni}_{\text {bark }}=-0.13 \pm 0.09 \%$, respectively. However, the 454 anomalously low Ni concentration in this sample collected at $5 \mathrm{~m}$ suggests a collection error and, therefore, it 455 will not be included in the further discussion.

\section{Discussion}

457

458

\section{Nickel isotopic composition in soil}

The studied soil samples have two distinct stages of pedogenesis, which are reflected not only by the overall element concentrations and associated mineralogy, but also by their $\mathrm{Ni}$ isotopic composition. Weathering processes are expected to influence $\delta^{60} \mathrm{Ni}$ by depleting the heavier fraction of Ni in soil (Ratié et al. 2015). This hypothesis is consistent with the lighter $\mathrm{Ni}$ isotopic signature of $\mathrm{SR}_{150}$ bulk $\left(\delta^{60} \mathrm{Ni}=-0.17 \pm 0.05\right)$ compare to $\mathrm{SR}_{600}$ bulk $\left(\delta^{60} \mathrm{Ni}=-0.01 \pm 0.05\right)$. The $\mathrm{SR}_{150}$ is a Ferralsol, collected near Serinsim region, and can be considered to have reached steady state equilibrium, as in Ferralsols all the alterable minerals have been weathered and secondary minerals carry most of the $\mathrm{Ni}$ in this soil. This assumption is supported by the soil mineralogy, characterized by a quasi-absence of phyllosilicates, and by the $\mathrm{Ni}$ solid speciation, showing that $\mathrm{Ni}$ is mainly bound to poorly crystalline Fe oxyhydroxides. Moreover, no difference is detected between the two first $\mathrm{SR}_{150}$ soil horizons $\mathrm{H} 1$ and $\mathrm{H} 2$, which have similar total and available Ni concentrations, and similar isotopic composition. The available $\mathrm{Ni}$ from $\mathrm{H} 1$ is slightly enriched in light isotopes $\left(\Delta^{60} \mathrm{Ni}_{\text {bulk- }}\right.$ available $=0.15 \pm 0.10 \%$, while no fractionation is observed for $\mathrm{H} 2\left(\Delta^{60} \mathrm{Ni}_{\text {bulk-avalable }}=-0.03 \pm 0.07 \%\right.$ o $)$. Such a stable isotopic composition of $\Delta^{60} \mathrm{Ni}_{\text {bulk-available }} \sim 0$, can be the result of the loss of the heavier water soluble $\mathrm{Ni}$ from the soil, due to full weathering of the primary minerals, achieved after thousands of years. In contrast, the soil $\mathrm{SR}_{600}$ is a partially weathered hypermagnesian Cambisol and the soil isotopic composition suggests the contribution of other processes than in $\mathrm{SR}_{150}$. Primary and secondary phyllosilicates, in which $\mathrm{Ni}$ is often present 
in structural positions and/or adsorbed onto the surface forming outer-sphere complexes (Chardot et al. 2007; Raous et al. 2013; Bani et al. 2014), are the main crystalline phases. To a lesser extent, Ni is also associated to amorphous $\mathrm{Fe}$ oxides (Fig.1). Both total $\mathrm{Ni}$ concentration and $\delta^{60} \mathrm{Ni}$ values in bulk soils remain constant in the three horizons of $\mathrm{SR}_{600}$, i.e. $\mathrm{H} 1, \mathrm{H} 2$ and $\mathrm{H} 3$. However, from $\mathrm{H} 1$ to $\mathrm{H} 3$, available Ni concentration decreases with depth and has a clear enrichment of heavy isotopes, with $\delta^{60} \mathrm{Ni}$ values increasing from $0.32 \%$ to $0.62 \%$ from $\mathrm{H} 1$ to $\mathrm{H} 3$, respectively. These values are directly correlated with a decreasing of exchangeable Ni (see CEC values in Table SI 2), a decreasing of organic $\mathrm{C}$, and an increasing of Fe content. Performing water extraction provides an estimation of the available Ni mainly involved in weak bonds with mineral surface groups or organic matter. Such a contribution to the available pool of $\mathrm{Ni}$ in surface horizon of ultramafic soils has already been noted (Zelano et al. 2015). The contribution of organic matter (OM) to available Ni is, therefore, likely more important in $\mathrm{H} 1$ and $\mathrm{H} 2$ than in $\mathrm{H} 3$, and it can be hypothesized that the increasing positive values of $\delta^{60} \mathrm{Ni}_{\text {available }}$ in $\mathrm{H} 2$ and $\mathrm{H} 3$, are due to a lower proportion of weakly bound $\mathrm{Ni}$ in those horizons compared to $\mathrm{SR}_{600} \mathrm{H} 1$. In the light of the results, it can be assumed that the lighter pool of available $\mathrm{Ni}$ in $\mathrm{SR}_{600} \mathrm{H} 1$ is the result of combined processes, such as the prolonged $\mathrm{Ni}$ uptake by plant and the leaf litter degradation, during which $\mathrm{Ni}$ is released to surface soil, in primis to $\mathrm{H} 1$. Reported results have shown that $\mathrm{Ni}$ isotopic composition of the whole plant $\mathrm{R}_{150}$ is lighter than the available $\mathrm{Ni}$ in soil (Table 5), suggesting that $R$. cf. bengalensis takes up lighter Ni isotopes. This hypothesis can be reasonably extrapolated to the case of $R_{600}$, for which the calculation of a mass balance was not possible, but in which all plant material have an isotopic signature lighter than the available Ni in soil. In a previous study it has been shown that during leaf litter degradation process, about the $80 \%$ of Ni released has the same $\delta^{60} \mathrm{Ni}$ value of the original leaves, and that after a few days, a release of light isotopes occurs (Zelano et al. 2018). Therefore, the enrichment of lighter isotopes in the whole plant likely produces a release of lighter $\mathrm{Ni}$ isotopes during leaf litter degradation to topsoil, H1, compared to the deeper horizons, H2 and H3. However, this contribution might also vary depending on the potential isotopic fractionation between leaves and roots.

\section{Nickel fractionation within plants}

500 From the isotopic composition of both specimen $\mathrm{R}_{150}$ and $\mathrm{R}_{600}$, it can be concluded that $R$. cf. bengalensis 501 preferentially takes up the lighter $\mathrm{Ni}$ isotopes from the available Ni fraction in soil through absorption by root cells, as reported in Table 5. This result is consistent with previously published data for Ni hyperaccumulators grown in hydroponics, where it was also shown that the entity of the fractionation was due to a competition effect, induced by the concomitant presence of other metals, e.g. Zn (Deng et al. 2014). In the case of Zn 
accumulation in wheat, a non-hyperaccumulating plant, it has been reported that the variation of $\mathrm{Zn}$ supply can be a source of different trends of $\mathrm{Zn}$ isotopic fractionation in the soil-plant system. The lower availability of $\mathrm{Zn}$ could enhance the release of organic ligands, such as phytosiderophores by the plant (Arnold et al. 2010), and thus the $\mathrm{Zn}$ uptake from soil, with subsequent enrichment of the plant in heavy isotopes (Wiggenhauser et al. 2018). However, hyperaccumulators often have more specific processes of uptake and translocation of metals than non-accumulating plants. For example, the $\mathrm{Zn}$ hyperaccumulator $N$. caerulescens has the ability to use both 511 high- and low-affinity transport systems depending on $\mathrm{Zn}$ availability, and this behaviour probably induces different trends of $\mathrm{Zn}$ isotopic fractionation in the plants (Deng et al. 2014). In our case, the investigated $R$. cf.

513 bengalensis grew on ultramafic soils, and neither the scarcity of Ni nor the competition effect with other metals 514 can be considered as relevant factors determining $\mathrm{Ni}$ isotopic fractionation in the soil-plant system. In 515 hyperaccumulating plants, it has been assumed that $\mathrm{Ni}$ is taken up through a symplastic pathway, and that $\mathrm{Ni}$ isotopic composition in whole plant derives from the uptake mechanisms of root cell membrane (Deng et al.

517 2014), promoting the uptake of lighter isotopes. Different pathways of fractionation within the plant parts can, 518 then, take place, but they are far from being fully understood. It has been recently reported that in wheat plants, 519 important $\mathrm{Zn}$ isotopic fractionation within plant parts can be attributed to the absorption of heavy isotopes to cell walls in the apoplastic space (Wiggenhauser et al. 2018). However, through experiments based on the use of radioactive ${ }^{63} \mathrm{Ni}$, it was reported that $\mathrm{Ni}$ is transferred from roots to shoots via xylem, and also that its mobility is greater than that of $\mathrm{Zn}, \mathrm{Mn}, \mathrm{Co}$ and $\mathrm{Cd}$ (Page and Feller 2005). These observations suggest that in hyperaccumulators, Ni undergoes a very efficient translocation process that might not be the only source of isotopic fractionation, or at most, it is responsible for the smaller isotopic fractionation observed for Ni compared to e.g. Zn (Deng et al. 2014; Wiggenhauser et al. 2018) and Cd (Wiggenhauser et al. 2016). Whereas some publications report demonstrations or assumptions about the translocation mechanisms of $\mathrm{Ni}$ (Kerkeb and

527 Krämer 2003; Alves et al. 2011), nothing is known about this mechanism for $R$. cf. bengalensis. In this study, reported XAFS spectra on $R$. cf. bengalensis (Fig.3, Table 3) show that $\mathrm{Ni}$ in leaves is unequivocally present as a complex with low molecular weight carboxylic acids (i.e. malate and citrate), confirming results reported by van der Ent et al. (2017).

In the case of $\mathrm{Zn}$ and $\mathrm{Cd}$, the isotopic fractionation in wheat shoots has been attributed to their different affinity

533 for functional groups of organic ligands (Wiggenhauser et al. 2018), or different chemical speciation. The 534 hypothesis about the possible influence of complexation with organic ligands on $\mathrm{Ni}$ isotopic fractionation was 
535 previously investigated (Zelano et al. 2018). However, a rather low potential of fractionation induced by 536 complexation reaction between $\mathrm{Ni}$ and citric acid, oxalic acid and purified humic substances was reported with a 537 maximum value of $\Delta^{60} \mathrm{Ni}_{\text {bond-free }}<0.2 \%$. Such a small fractionation can be excluded as a source of $\Delta^{60} \mathrm{Ni}$ within 538 plant material, discarding the hypothesis raised up for $\mathrm{Zn}$ fractionation in wheat shoots. The observed $\Delta^{60} \mathrm{Ni}$ 539 values within the two investigated specimen of $R$. cf. bengalensis cannot be fully explained by a complexation 540 reaction or by different affinity towards organic molecules.

542 Despite only two specimens have been investigated in this work, one possible interpretation for the observed $543 \Delta^{60} \mathrm{Ni}$ might come from the different age of the two $R$. cf. bengalensis plants. Even though they grew on different 544 soils, both plants take up lighter Ni isotopes and the reported results suggest a correlation between the plant age 545 and the observed $\Delta^{60} \mathrm{Ni}$ values. Both specimens have the highest concentration of $\mathrm{Ni}$ in leaves, confirming that $546 \mathrm{Ni}$ is never stored in roots, but it is rapidly transferred to them, as it expected for Ni hyperaccumulators that do 547 not require defence mechanisms against high Ni concentration in soil. In the early stage of growth of the plant $548\left(\mathrm{R}_{150}\right), 80 \%$ of the total amount of $\mathrm{Ni}$ is mobilized and more than $70 \%$ is concentrated in leaves. This transfer 549 produces a remarkable isotopic fractionation between leaves and roots, from which a preferentially translocation 550 of lighter isotopes, $\Delta^{60} \mathrm{Ni}_{\text {root-leaf }}$ up to $0.51 \pm 0.07 \%$, can be observed (Table 5). At the same time, an enrichment 551 of heavier isotopes in the ligneous parts of the plant is present. As the total amount of $\mathrm{Ni}$ in leaves is definitively 552 higher than in wood and bark, these results strongly suggest that lighter isotopes are transferred first, going from 553 roots to leaves. Data reported in Fig. 4 suggest, moreover, that the fractionation is correlated to the rate of Ni 554 translocation (lighter isotopes move faster) as an important fractionation is also observed as a function of height, 555 between younger (apical) and older (basal) parts of the plant. This implies that as soon as new leaves appear, Ni 556 is mobilized through leaves, and lighter isotopes arrive first. This trend is no longer observed in the older 557 specimen $\left(\mathrm{R}_{600}\right)$, where the isotopic fractionation between basal and apical leaves is not evident anymore. This 558 result is surprising as $\mathrm{Ni}$ concentration still shows a clear trend between the apical and basal leaves, higher in 559 basal, and lower in apical ones. Moreover, the isotopic fractionation between leaves and other plant material is 560 less pronounced in the older specimen than in the younger plant (see Fig.4). This observation suggests that the 561 fractionation observed in $\mathrm{R}_{150}$ is not necessarily attributable to different transport or retention mechanisms, as it 562 is hypothesized for other metals, e.g. Cd (Wiggenhauser et al. 2016). If the fractionation were due to transport or 563 retention mechanisms, it would be accentuated in the older plant, but the opposite result is observed. In addition, 

enriched in heavier isotopes compared to roots.

Taken together, the available data suggest that during the first period of growth, when the plant starts to take up

$568 \mathrm{Ni}$, the transfer of light isotopes from roots to leaves can be due to kinetic effects. Once the amount of $\mathrm{Ni}$ accumulated in the plant has increased (see Ni concentration in $\mathrm{R}_{600}$, Table 4), the Ni already present in the plant circulates through the phloem tissue into all plant parts. Successive loading and unloading cycles would have, therefore, the effect to homogenize the isotopic fractionation among leaves, and between leaves and the other

572 plant components, erasing the difference between new and old leaves. In old specimens, the consequent increasing number of cycles that $\mathrm{Ni}$ makes within the plant through the circulation of phloem sap from top to bottom, and inversely, would reduce the isotopic fractionation. The observed data in $\mathrm{R}_{600}$ are probably the results of several additive processes and support the idea that in the hyperaccumulator $R$. cf. bengalensis, $\mathrm{Ni}$ is involved in plant homeostasis as any other cation. However, to confirm this hypothesis, supplementary data should be collected on a wider population of trees of $R$. cf. bengalensis, collected in their natural habitat and at different stage of growth.

\section{Conclusions}

580 This study aimed to unravel the biogeochemical processes resulting in Ni isotopic fractionation in two different

581 soil-plant systems associated with the Ni hyperaccumulator plant $R$. cf. bengalensis. The investigated soils have 582 distinct stages of pedogenesis, which are both highlighted by the mineralogical composition and the isotopic 583 signature of the available pool of $\mathrm{Ni}$. The Ferralsol $\mathrm{SR}_{150}$ reflects a stable system, which has reached a steadystate equilibrium, subsequent to the complete weathering of primary minerals and for which Ni is mainly associated to poorly crystalline Fe-oxyhydroxides. The isotopic signature has no variation, neither in soil bulk surface horizons, nor in the available pool of $\mathrm{Ni}$. In the partially weathered hypermagnesian Cambisol $\mathrm{SR}_{600}, \mathrm{Ni}$

587 is associated not only to Fe-oxyhydroxides, but also to the identified phyllosilicates, and even though the Ni isotopic composition of bulk soils does not vary, an enrichment in heavy isotopes is observed with depth for the

589 Ni available fraction. In both soil systems, the two investigated specimens of the hyperaccumulator $R$. cf. bengalensis accumulate lighter $\mathrm{Ni}$ isotopes from the soil available $\mathrm{Ni}$ pool. The $\mathrm{Ni}$ isotopic composition in the different parts of the plants were investigated and correlated to the plant height and age. Despite the limited 
in hyperaccumulator plants. A translocation of lighter isotopes of $\mathrm{Ni}$ from roots to leaves was observed in the young plant, $\Delta^{60} \mathrm{Ni}_{\text {root-leaf }}$ up to $0.51 \pm 0.07 \%$, and isotopic fractionation was also unravelled between the apical and basal leaves, $\Delta^{60} \mathrm{Ni}_{\text {basal-apical }}$ up to $0.23 \pm 0.07 \%$ (Table 5). However, this effect was not detected in the older plant, where no isotopic fractionation was observed as a function of plant height, and where the $\mathrm{Ni}$ isotopic

597 fractionation seems to be mask by successive cycles of Ni circulation through the plant. These results suggest that once $\mathrm{Ni}$ is taken up from the soil by roots, it is rapidly transferred to leaves, without being permanently stored there. Instead, it has an active and continuous cycle within the plant through phloem-mediated redistribution. Once the plant has accumulated a substantial quantity of $\mathrm{Ni}$, the isotopic fractionation induced by

601 Ni translocation among aerial plant material is masked by an isotopic homogenization, and the observed isotopic signature is the result of consecutive internal translocation cycles. However, it is still not clear why the roots of the older specimen have a lighter isotopic signature than in aerial parts.

604

The acquired results suggest that it is inordinately difficult to discriminate between specific, individual processes leading to $\mathrm{Ni}$ isotopic fractionation during $\mathrm{Ni}$ sorption and translocation within the plant, especially for hyperaccumuating plants. The comparison of two plants with a different stage of growth seems to highlight the role of plant's age on Ni isotopic fractionation. However, to better constrain Ni homeostasis and the contribution of $R$. cf. bengalensis to $\mathrm{Ni}$ isotopic signature in surface soil, more specimens should be investigated and

\section{Acknowledgements}

613 We thank Sabah Parks for granting permission to conduct research in Kinabalu Park, and the Sabah Biodiversity

614 Council for research permits. A. van der Ent is the recipient of a Discovery Early Career Researcher Award 615 (DE160100429) from the Australian Research Council. We thank Emile Benizri, Séverine Lopez, Celestino 616 Quintela-Sabaris and Sukaibin Sumail for their support during sampling campaign. We acknowledge IJL and

617 Mrs. Migot for access to TEM facilities. Parts of this research were carried out at SAMBA beamline at SOLEIL, 618 and at XAFS beamline from ELETTRA Synchrotron facility. We would like to thank Emiliano Fonda 619 (SOLEIL), Luca Olivi (ELETTRA) for assistance during the experiments. The research leading to this result has 620 been supported by the project CALIPSOplus under the Grant Agreement 730872 from the EU Framework 621 Programme for Research and Innovation HORIZON 2020. The authors would like to thank Agence Nationale de 
contribution $\mathrm{N}^{\circ} 2567$. The authors also would like to thank the two anonymous reviewers for their useful

suggestions that helped improving the quality of the manuscript.

625

626

\section{References}

627

Alves S, Nabais C, Simoes Goncalves M de L, Correia dos Santos MM (2011) Nickel speciation in the xylem sap of the hyperaccumulator Alyssum serpyllifolium ssp. lusitanicum growing on serpentine soils of northeast Portugal. J Plant Physiol 168:1715-1722. doi: 10.1016/j.jplph.2011.04.004

Arnold T, Kirk GJD, Wissuwa M, et al (2010) Evidence for the mechanisms of zinc uptake by rice using isotope fractionation. Plant, Cell Environ 33:370-381. doi: 10.1111/j.1365-3040.2009.02085.x

Aucour A-M, Bedell J-P, Queyron M, et al (2015) Dynamics of Zn in an urban wetland soil-plant system: Coupling isotopic and EXAFS approaches. Geochim Cosmochim Acta 160:55-69. doi: 10.1016/J.GCA.2015.03.040

Aucour AM, Bedell JP, Queyron M, et al (2017) Zn Speciation and Stable Isotope Fractionation in a Contaminated Urban Wetland Soil-Typha latifolia System. Environ Sci Technol 51:8350-8358. doi: 10.1021/acs.est.6b02734

Baker AJM Metal Tolerance. New Phytol. 106:93-111

Baker AJM (1981) Accumulators and excluders strategies in the response of plants to heavy metals. J Plant Nutr 3:643-654. doi: 10.1080/01904168109362867

Baker AJM, Brooks RR (1988) Botanical Exploration for Minerals in the Humid Tropics. J Biogeogr 15:221. doi: $10.2307 / 2845062$

Bani A, Echevarria G, Montargès-Pelletier E, et al (2014) Pedogenesis and nickel biogeochemistry in a typical Albanian ultramafic toposequence. Environ Monit Assess 186:4431-4442. doi: 10.1007/s10661-014-37096

Becquer T, Quantin C, Rotte-Capet S, et al (2006) Sources of trace metals in Ferralsols in New Caledonia. Eur J Soil Sci 57:200-213. doi: 10.1111/j.1365-2389.2005.00730.x

Bonifacio E, Zanini E, Boero V, Franchini-Angela M (1997) Pedogenesis in a soil catena on serpentinite in north-western Italy. Geoderma 75:33-51. doi: 10.1016/S0016-7061(96)00076-6

Boyd RS, Martens SN (1998) The significance of metal hyperaccumulation for biotic interactions. Chemoecology 8:1-7. doi: 10.1007/s000490050002

Caldelas C, Weiss DJ (2017) Zinc Homeostasis and isotopic fractionation in plants: a review. Plant Soil 411:1746. doi: 10.1007/s11104-016-3146-0

Cameron V, Vance D, Archer C, House CH (2009) A biomarker based on the stable isotopes of nickel. Proc Natl Acad Sci U S A 106:10944-8. doi: 10.1073/pnas.0900726106

Cataldo DA, Garland TR, Wildung RE (1978) Nickel in Plants: I. Uptake Kinetics Using Intact Soybean Seedlings. PLANT Physiol 62:563-565. doi: 10.1104/pp.62.4.563

Chardot V, Echevarria G, Gury M, et al (2007) Nickel bioavailability in an ultramafic toposequence in the 
and Nonaccumulating Plants. Environ Sci Technol 48:11926-11933. doi: 10.1021/es5020955

Deng T-H-B, Tang Y-T, Sterckeman T, et al (2019) Effects of the interactions between nickel and other trace metals on their accumulation in the hyperaccumulator Noccaea caerulescens. Environ Exp Bot 158:73-79. doi: 10.1016/j.envexpbot.2018.11.015

Deng T-H-B, van der Ent A, Tang Y-T, et al Nickel hyperaccumulation mechanisms: a review on the current state of knowledge. doi: 10.1007/s11104-017-3539-8

Echevarria G, Massoura ST, Sterckeman T, et al (2006) Assessment and control of the bioavailability of nickel in soils. Environ Toxicol Chem 25:643-651. doi: 10.1897/05-051r.1

Elliott T, Steele RCJ (2017) The Isotope Geochemistry of Ni. Rev Mineral Geochemistry 82:511-542. doi: 10.2138/rmg.2017.82.12

Estrade N, Cloquet C, Echevarria G, et al (2015) Weathering and vegetation controls on nickel isotope fractionation in surface ultramafic environments (Albania). Earth Planet Sci Lett 423:24-35. doi: 10.1016/j.eps1.2015.04.018

Gall L, Williams HM, Siebert C, et al (2013) Nickel isotopic compositions of ferromanganese crusts and the constancy of deep ocean inputs and continental weathering effects over the Cenozoic

Gueguen B, Rouxel O, Ponzevera E, et al (2013) Nickel Isotope Variations in Terrestrial Silicate Rocks and Geological Reference Materials Measured by MC-ICP-MS. Geostand Geoanalytical Res 37:297-317. doi: 10.1111/j.1751-908X.2013.00209.X

Gueguen B, Sorensen J V., Lalonde S V., et al (2018) Variable Ni isotope fractionation between Feoxyhydroxides and implications for the use of $\mathrm{Ni}$ isotopes as geochemical tracers. Chem Geol. doi: 10.1016/j.chemgeo.2018.01.023

Guelke M, von Blanckenburg F (2007) Fractionation of Stable Iron Isotopes in Higher Plants. Environ Sci Technol 41:1896-1901. doi: 10.1021/es062288j

Imseng M, Wiggenhauser M, Keller A, et al (2019) Towards an understanding of the Cd isotope fractionation during transfer from the soil to the cereal grain. Environ Pollut 244:834-844. doi: 10.1016/j.envpol.2018.09.149

Imseng M, Wiggenhauser M, Keller A, et al (2018) Fate of Cd in Agricultural Soils: A Stable Isotope Approach to Anthropogenic Impact, Soil Formation, and Soil-Plant Cycling. Environ Sci Technol 52:1919-1928. doi: 10.1021/acs.est.7b05439

Jaffre T, Brooks RR, Lee J, Reeves RD (1976) Sebertia acuminata: A Hyperaccumulator of Nickel from New Caledonia. Science (80- ) 193:579-580. doi: 10.1126/science.193.4253.579

Jaffré T, Reeves RD, Baker AJM, et al (2018) The discovery of nickel hyperaccumulation in the New Caledonian tree Pycnandra acuminata 40 years on: an introduction to a Virtual Issue. New Phytol 218:397-400. doi: 10.1111/nph.15105

Jouvin D, Weiss DJ, Mason TFM, et al (2012) Stable Isotopes of Cu and Zn in Higher Plants: Evidence for Cu Reduction at the Root Surface and Two Conceptual Models for Isotopic Fractionation Processes. Environ Sci Technol 46:2652-2660. doi: 10.1021/es202587m

699 Kerkeb L, Krämer U (2003) The Role of Free Histidine in Xylem Loading of Nickel in Alyssum lesbiacum and Brassica juncea 1. Plant Physiol 131:716-724. doi: 10.1104/pp102.010686 
hyperaccumulation in the vascular tracts of the tree Phyllanthus balgooyi from Borneo. New Phytol 209:1513-1526. doi: 10.1111/nph.13712

Nkrumah PN, Echevarria G, Erkine PD, et al (2019a) Growth responses of two tropical nickel hyperaccumulator plant species to nutrient dosing. J Plant Nutr Soil Sc 182(5): 715-728.

Nkrumah PN, Echevarria G, Erskine PD, et al (2019b) Soil amendments affecting nickel uptake and growth performance of tropical 'metal crops' used for agromining. J Geochemical Explor 203:78-86. doi: 10.1016/j.gexplo.2019.03.009

Nkrumah PN, Echevarria G, Erskine PD, Chaney RL, Sumail S, van der Ent A (2019c) Effect of nickel concentration and soil $\mathrm{pH}$ on metal accumulation and growth in tropical agromining 'metal crops'. Plant Soil 443(1): 27-39.

Nkrumah PN, Tisserand R, Chaney RL, et al (2019d) The first tropical 'metal farm': Some perspectives from field and pot experiments. J Geochemical Explor 198:114-122. doi: 10.1016/J.GEXPLO.2018.12.003

Page V, Feller U (2005) Selective transport of zinc, manganese, nickel, cobalt and cadmium in the root system and transfer to the leaves in young wheat plants. Ann Bot 96:425-434. doi: 10.1093/aob/mci189

Raous S, Echevarria G, Sterckeman T, et al (2013) Potentially toxic metals in ultramafic mining materials: Identification of the main bearing and reactive phases. Geoderma 192:111-119. doi: 10.1016/j.geoderma.2012.08.017

Ratié G, Jouvin D, Garnier J, et al (2015) Nickel isotope fractionation during tropical weathering of ultramafic rocks. Chem Geol 402:68-76. doi: 10.1016/j.chemgeo.2015.02.039

Ratié G, Quantin C, Maia De Freitas A, et al (2019) The behavior of nickel isotopes at the biogeochemical interface between ultramafic soils and Ni accumulator species. J Geochemical Explor 196:182-191. doi: 10.1016/J.GEXPLO.2018.10.008

Ravel B, Newville M (2005) ATHENA, ARTEMIS, HEPHAESTUS: data analysis for X-ray absorption spectroscopy using IFEFFIT. J Synchrotron Radiat 12:537-541. doi: 10.1107/S0909049505012719

Reeves RD (2003) Tropical hyperaccumulators of metals and their potential for phytoextraction. Plant Soil 249:57-65. doi: 10.1023/A:1022572517197

Reeves RD, Baker AJM, Jaffré T, et al (2018a) A global database for plants that hyperaccumulate metal and metalloid trace elements. New Phytol 218:407-411. doi: 10.1111/nph.14907

Reeves RD, Baker AJM, Jaffré T, et al (2018b) A global database for plants that hyperaccumulate metal and metalloid trace elements. New Phytol 218:407-411. doi: 10.1111/nph.14907

Rehr JJ, Kas JJ, Vila FD, et al (2010) Parameter-free calculations of X-ray spectra with FEFF9. Phys Chem Chem Phys 12:5503-5513. doi: 10.1039/b926434e

Spivak-Birndorf LJ, Wang SJ, Bish DL, Wasylenki LE (2018) Nickel isotope fractionation during continental weathering. Chem Geol 476:316-326. doi: 10.1016/j.chemgeo.2017.11.028

Tang Y-T, Cloquet C, Deng T-H-B, et al (2016) Zinc Isotope Fractionation in the Hyperaccumulator Noccaea caerulescens and the Nonaccumulating Plant Thlaspi arvense at Low and High Zn Supply. Environ Sci Technol 50:8020-8027. doi: 10.1021/acs.est.6b00167 120827161207002. doi: 10.1021/es3015056 
van der Ent A, Baker AJM, Reeves RD, et al (2013) Hyperaccumulators of metal and metalloid trace elements: Facts and fiction. Plant Soil 362:319-334. doi: 10.1007/s11104-012-1287-3

van der Ent A, Mulligan DM (2015) Multi-element Concentrations in Plant Parts and Fluids of Malaysian Nickel Hyperaccumulator Plants and some Economic and Ecological Considerations. J Chem Ecol 41:396-408. doi: 10.1007/s10886-015-0573-y van der Ent A, Erskine PD, Sumail S (2015) Ecology of nickel hyperaccumulator plants from ultramafic soils in Sabah (Malaysia). Chemoecology 25:243-259. doi: 10.1007/s00049-015-0192-7

van der Ent A, Callahan DL, Noller BN, et al (2017) Nickel biopathways in tropical nickel hyperaccumulating trees from Sabah (Malaysia). Sci Rep 7:. doi: DOI: 10.1038/srep41861

van der Ent A, Cardace D, Tibbett M, Echevarria G (2018a) Ecological implications of pedogenesis and geochemistry of ultramafic soils in Kinabalu Park (Malaysia). Catena 160:154-169. doi: 10.1016/j.catena.2017.08.015

van der Ent A, Mulligan DR, Repin R, Erskine PD (2018b) Foliar elemental profiles in the ultramafic flora of Kinabalu Park (Sabah, Malaysia). Ecol Res 33:659-674. doi: 10.1007/s11284-018-1563-7

van der Ent A, Przybyłowicz WJ, de Jonge MD, et al (2018c) X-ray elemental mapping techniques for elucidating the ecophysiology of hyperaccumulator plants. New Phytol 218:432-452. doi: $10.1111 /$ nph.14810

van der Ent A, Ocenar A, Tisserand R, Sugau JB, Erskine PD, Echevarria G (2019a) Herbarium X-ray Fluorescence Screening for nickel, cobalt and manganese hyperaccumulation in the flora of Sabah (Malaysia, Borneo Island). J Geochem Explor 202: 49-58.

van der Ent A, Nkrumah PN, Echevarria G, Tibbett M (2019b) Evaluating soil extraction methods for chemical characterization of ultramafic soils in Kinabalu Park (Malaysia). J Geochem Explor 196: 235-246.

van der Ent A, de Jonge MD, Mak R, Mesjasz-Przybylowicz J, Przybylowicz WJ, Barnabas AD, Hugh HH (2020) X-ray fluorescence elemental mapping of roots, stems and leaves of the nickel hyperaccumulators Rinorea cf. bengalensis and Rinorea cf. javanica (Violaceae) from Sabah (Malaysia), Borneo. Plant Soil. In Press. doi:10.1007/s11104-019-04386-2

Vitousek PM (1984) Litterfall, Nutrient Cycling, and Nutrient Limitation in Tropical Forests. Ecology 65:285298. doi: $10.2307 / 1939481$

Vitousek PM, Sanford RL (1986) Nutrient Cycling in Moist Tropical Forest. Annu Rev Ecol Syst 17:137-167. doi: 10.1146/annurev.es.17.110186.001033

Wang SJ, Wasylenki LE (2017) Experimental constraints on reconstruction of Archean seawater Ni isotopic composition from banded iron formations. Geochim Cosmochim Acta 206:137-150. doi: 10.1016/j.gca.2017.02.023

Wasylenki LE, Howe HD, Spivak-Birndorf LJ, Bish DL (2015) Ni isotope fractionation during sorption to ferrihydrite: Implications for Ni in banded iron formations. Chem Geol 400:56-64. doi: 10.1016/j.chemgeo.2015.02.007

Weiss DJ, Mason TFD, Zhao FJ, et al (2004) Isotopic discrimination of zinc in higher plants. New Phytol 165:703-710. doi: 10.1111/j.1469-8137.2004.01307.x

Whittaker RH (1954) The Ecology of Serpentine Soils. Ecology 35:258-288. doi: 10.2307/1931126

Wiggenhauser M, Bigalke M, Imseng M, et al (2018) Zinc isotope fractionation during grain filling of wheat and 

a comparison of zinc and cadmium isotope ratios in identical soil-plant systems. New Phytol 219:195205. doi: $10.1111 / \mathrm{nph} .15146$

784 Wiggenhauser M, Bigalke M, Imseng M, et al (2016) Cadmium Isotope Fractionation in Soil-Wheat Systems. Environ Sci Technol 50:9223-9231. doi: 10.1021/acs.est.6b01568

Zelano I, Sivry Y, Quantin C, et al (2015) Study of Ni exchangeable pool speciation in ultramafic and mining environments with isotopic exchange kinetic data and models. Appl Geochemistry 1-11. doi: 10.1016/j.apgeochem.2015.09.021

Zelano IO, Cloquet C, Fraysse F, et al (2018) The influence of organic complexation on Ni isotopic fractionation and Ni recycling in the upper soil layers. Chem Geol 483:47-55. doi: 10.1016/J.CHEMGEO.2018.02.023 
Table 1. Nickel concentration, $\mu \mathrm{mol} \mathrm{g} \mathrm{g}^{-1}$, and isotopic composition $\delta^{60} \mathrm{Ni}$, in: i) bulk soil horizons collected at the bottom of $R$. cf. bengalensis $\mathrm{R}_{150}$ and $\mathrm{R}_{600}$; reported results are the average of three measurements for each sample with the corresponding instrumental standard deviation $\sigma$. The standard deviation obtained for the Ni ICP- MS standard solution $\left(\delta^{60} \mathrm{Ni}=-0.11 \pm 0.05 \%\right)$ was applied to all sample results presenting analytical error $2 \sigma<0.05 \%$. ii) Concentration and isotopic composition of $\mathrm{Ni}$ in solution after $24 \mathrm{~h}$ of soil suspension in ultrapure water. Results are the average of triplicate samples and $\sigma$ values were calculated as described in eq. $2, \sigma=\frac{s d}{\sqrt{N}}$, where $s d$ is the standard deviation of the sample mean, and $\mathrm{N}$ is the number of samples. The reference material BHVO-2 was processed and measured ten times, obtaining $\delta^{60} \mathrm{Ni}=0.05 \pm 0.04 \%$ ( $(2 \sigma)$.

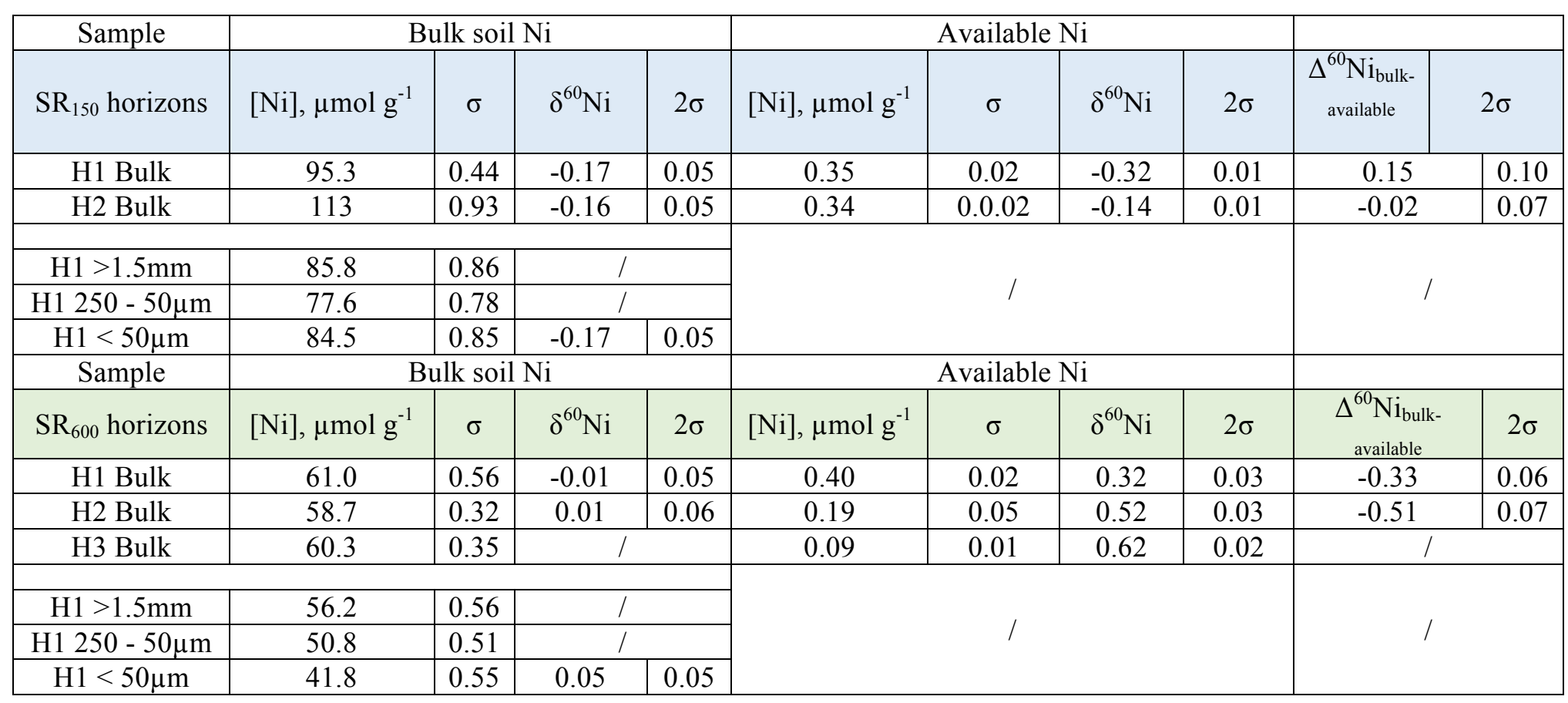


Table 2. XAS data on $\mathrm{SR}_{150}$ and $\mathrm{SR}_{600}$ bulk soils, $\mathrm{H} 1$ horizons. 1-Summary of the local structural parameters derived from EXAFS data analysis (shell by shell fitting). The Ni EXAFS data were Fourier transformed over the k range $\Delta \mathrm{k}$ and fitted over the $\Delta \mathrm{R}$ range to four single scattering paths involving $\mathrm{O}, \mathrm{Fe}$ or $\mathrm{Si}$ atoms. The amplitude reduction factor $\mathrm{S}_{0}{ }^{2}$ was fixed to 0.9 as well as the energy shift on the basis of reference spectra analysis. The number of atoms of the first coordination shell was fixed to 6 , but the number of atoms of other coordination shells was released. The distance $\mathrm{R}$ and disorder $\Delta^{2}$ were varied for all the coordination shells. 2- Linear combination fitting was obtained on the fitting range $\Delta \mathrm{k}$ using as a maximum three components: Ni sorbed onto a purified clay in position of exchangeable cation, Ni sorbed onto goethite and $\mathrm{Ni}$ as structural cation in serpentine mineral.

\begin{tabular}{|c|c|c|c|c|c|c|c|c|c|}
\hline \multicolumn{10}{|c|}{ 1-Structural parameters } \\
\hline & $\begin{array}{c}\text { Fitting range } \\
\Delta \mathrm{k}\left(\AA^{-1}\right)\end{array}$ & $\begin{array}{c}\text { Fitting } \\
\text { range } \Delta R \\
(\AA)\end{array}$ & shell & $\begin{array}{l}\text { Number of } \\
\text { atoms }\end{array}$ & $R(\AA ̊)$ & $\sigma^{2}\left(\AA^{2}\right)$ & $\Delta \mathrm{E}(\mathrm{eV})$ & $\mathrm{S}_{0}{ }^{2}$ & $\mathrm{R}$ factor \\
\hline \multirow{4}{*}{$\mathrm{SR}_{150}$} & \multirow{4}{*}{$2.2-10$} & \multirow{4}{*}{$1.1-4$} & $\mathrm{Ni}-\mathrm{O}$ & 6 & $2.030 \pm 0.01$ & $0.00418 \pm 0.001$ & \multirow{4}{*}{-5.79} & \multirow{4}{*}{0.90} & \multirow{4}{*}{0.00015} \\
\hline & & & $\mathrm{Ni}-\mathrm{Fe}$ & $1.3 \pm 0.5$ & $3.066 \pm 0.01$ & $0.00423 \pm 0.001$ & & & \\
\hline & & & $\mathrm{Ni}-\mathrm{Fe}$ & $1.2 \pm 0.7$ & $3.54 \pm 0.02$ & $0.00618 \pm 0.0012$ & & & \\
\hline & & & $\mathrm{Ni}-\mathrm{O}$ & $2.6 \pm 0.6$ & $3.82 \pm 0.02$ & $0.00411 \pm 0.001$ & & & \\
\hline \multirow{4}{*}{$\mathrm{SR}_{600}$} & \multirow{4}{*}{$2.5-10.4$} & \multirow{4}{*}{$1.1-4$} & $\mathrm{Ni}-\mathrm{O}$ & 6 & $2.058 \pm 0.01$ & $0.00454 \pm 0.001$ & \multirow{4}{*}{-4.12} & \multirow{4}{*}{0.90} & \multirow{4}{*}{0.000038} \\
\hline & & & $\mathrm{Ni}-\mathrm{Fe}$ & $0.7 \pm 0.6$ & $3.118 \pm 0.01$ & $0.0049 \pm 0.001$ & & & \\
\hline & & & $\mathrm{Ni}-\mathrm{Si}$ & $1.6 \pm 0.6$ & $3.261 \pm 0.02$ & $0.0051 \pm 0.0015$ & & & \\
\hline & & & $\mathrm{Ni}-\mathrm{O}$ & $3 \pm 0.6$ & $3.92 \pm 0.02$ & $0.0050 \pm 0.0009$ & & & \\
\hline \multicolumn{10}{|c|}{ 2-Linear combination fitting parameters } \\
\hline & $\begin{array}{c}\text { Fitting range } \\
\Delta \mathrm{k}\left(\AA^{-1}\right)\end{array}$ & $\begin{array}{l}\text { Ni sorbed } \\
\text { onto Clay }\end{array}$ & Ni-Goethite & $\begin{array}{c}\mathrm{Ni}- \\
\text { Serpentine }\end{array}$ & & & & & $\mathrm{R}$ factor \\
\hline $\mathrm{SR}_{150}$ & $2-10$ & $50.3+5$ & $49.7 \pm 5$ & & & & & & 0.098 \\
\hline $\mathrm{SR}_{600}$ & $2-10$ & $59 \pm 4$ & $16 \pm 2$ & $26 \pm 3$ & & & & & 0.054 \\
\hline
\end{tabular}


Table 3. XAS data on $R$. bengalensis leaves - Linear combination fitting was obtained on the fitting range $\Delta \mathrm{k}$ using as a maximum three components from a library of reference spectra obtained from organic complexes of $\mathrm{Ni}$ as well as from $\mathrm{Ni}$ aqueous solution. $\mathrm{Ni}$-malate, $\mathrm{Ni}$ histidine and Ni-citrate solutions were prepared at $\mathrm{pH} 6$ with a metal/ligand ratio of 7 .

\begin{tabular}{|c|c|c|c|c|c|c|}
\hline \multicolumn{7}{|c|}{ Linear combination fitting parameters } \\
\hline & Fitting range $\Delta \mathrm{k}\left(\AA^{-1}\right)$ & Ni aqueous & Ni-malate & Ni-histidine & Ni-citrate & $\mathrm{R}$ factor \\
\hline $\mathrm{R}_{150}$ & $2-10.5$ & $31 \pm 4$ & $42 \pm 8$ & & $27 \pm 4$ & 0.026 \\
\hline $\mathrm{R}_{600}$ & $2-10.5$ & $33 \pm 3$ & $41 \pm 6$ & & $26 \pm 4$ & 0.020 \\
\hline
\end{tabular}


Table 4. Plant mass $(\mathrm{g})$, Ni concentration $\left(\mu \mathrm{mol} \mathrm{g}{ }^{-1}\right)$ and isotopic composition $\left(\delta^{60} \mathrm{Ni}\right)$ of $R$. bengalensis $\mathrm{R}_{150}$ and $\mathrm{Ni}$ concentration $\left(\mu \mathrm{mol} \mathrm{g}^{-1}\right)$ and $\delta^{60} \mathrm{Ni}$ values of $\mathrm{R}_{600}$ specimens are reported, in blue and green, respectively. All results are the average of three measurements for each sample and the relative standard deviations correspond to the instrumental error. When the $2 \sigma$ associated to $\delta^{60} \mathrm{Ni}$ values are $<0.05 \%$, the value of $2 \sigma=$ $0.05 \%$ obtained for Oak Leaves reference material V464 $\left(\delta^{60} \mathrm{Ni}=-0.02 \pm 0.05 \%, \mathrm{~N}=6\right)$ is used. The Ni concentration and the $\delta^{60} \mathrm{Ni}$ of the whole plant have been calculated as the weighted average values. The corresponding $2 \sigma$ values are calculated according to equation 5 .

\begin{tabular}{|c|c|c|c|c|c|c|c|c|c|c|c|c|}
\hline $\mathbf{R}_{150}$ & Height & Mass, g & $\begin{array}{c}{[\mathrm{Ni}],} \\
\mu \mathrm{mol} \mathrm{g}^{-1}\end{array}$ & $\sigma$ & $\delta^{60} \mathrm{Ni}$ & $2 \sigma$ & $\mathbf{R}_{600}$ & Height & $\begin{array}{c}{[\mathrm{Ni}],} \\
\mu \mathrm{mol} \mathrm{g}^{-1}\end{array}$ & $\sigma$ & $\delta^{60} \mathrm{Ni}$ & $2 \sigma$ \\
\hline \multirow{5}{*}{ Leaf } & $50 \mathrm{~cm}$ & 6 & 171 & 1.10 & -0.66 & 0.05 & \multirow{5}{*}{ Leaf } & $2 \mathrm{~m}$ & 522 & 7.84 & -0.33 & 0.04 \\
\hline & $60 \mathrm{~cm}$ & 7.6 & 156 & 0.62 & -0.75 & 0.05 & & $3 \mathrm{~m}$ & 349 & 5.50 & -0.19 & 0.05 \\
\hline & $80 \mathrm{~cm}$ & 4.7 & 221 & 1.60 & -0.78 & 0.05 & & $4 \mathrm{~m}$ & 309 & 5.94 & -0.20 & 0.04 \\
\hline & $110 \mathrm{~cm}$ & 8.5 & 134 & 2.40 & -0.82 & 0.05 & & $5 \mathrm{~m}$ & 220 & 6.85 & -0.30 & 0.02 \\
\hline & $150 \mathrm{~cm}$ & 9.6 & 138 & 2.72 & -0.89 & 0.05 & & $6 \mathrm{~m}$ & 156 & 1.17 & -0.25 & 0.08 \\
\hline \multirow{7}{*}{ Bark } & & & & & & & \multirow{7}{*}{ Bark } & $-5 \mathrm{~cm}$ & 9.56 & 0.04 & 0.12 & 0.05 \\
\hline & $20 \mathrm{~cm}$ & 0.5 & 68.7 & 0.78 & -0.29 & 0.05 & & $1 \mathrm{~m}$ & 133 & 1.23 & -0.06 & 0.04 \\
\hline & $25 \mathrm{~cm}$ & 0.5 & 62.2 & 0.49 & -0.22 & 0.05 & & $2 \mathrm{~m}$ & 149 & 2.37 & -0.19 & 0.03 \\
\hline & $50 \mathrm{~cm}$ & 0.5 & 58.0 & 0.37 & -0.40 & 0.10 & & $3 \mathrm{~m}$ & 108 & 1.13 & -0.21 & 0.05 \\
\hline & $60 \mathrm{~cm}$ & 0.5 & 43.0 & 0.46 & -0.26 & 0.05 & & $4 \mathrm{~m}$ & 105 & 1.49 & -0.29 & 0.07 \\
\hline & $80 \mathrm{~cm}$ & 0.5 & 67.5 & 1.07 & -0.16 & 0.05 & & $5 \mathrm{~m}$ & 92.8 & 0.96 & -0.13 & 0.09 \\
\hline & $100 \mathrm{~cm}$ & 0.5 & 98.6 & 0.73 & -0.15 & 0.09 & & $6 \mathrm{~m}$ & 52.6 & 0.38 & 0.15 & 0.05 \\
\hline \multirow{6}{*}{ Wood } & $20 \mathrm{~cm}$ & 12.4 & 6.68 & 0.04 & -0.29 & 0.13 & \multirow{2}{*}{ Phloem } & $-5 \mathrm{~cm}$ & 545 & 7.05 & -0.60 & 0.08 \\
\hline & $25 \mathrm{~cm}$ & 1.81 & 9.39 & 0.12 & -0.32 & 0.05 & & $5 \mathrm{~m}$ & 11.7 & 0.17 & -0.10 & 0.06 \\
\hline & $50 \mathrm{~cm}$ & 18.9 & 15.6 & 0.15 & -0.13 & 0.07 & & & & & & \\
\hline & $60 \mathrm{~cm}$ & 2.35 & 11.9 & 0.11 & -0.17 & 0.05 & & & & & & \\
\hline & $80 \mathrm{~cm}$ & 1.34 & 28.1 & 0.38 & -0.05 & 0.05 & & & & & & \\
\hline & $100 \mathrm{~cm}$ & 0.76 & 69.9 & 0.62 & -0.50 & 0.05 & & & & & & \\
\hline \multirow{2}{*}{ Root } & $-5 \mathrm{~cm}$ & 10 & 81.7 & 0.95 & -0.35 & 0.05 & \multirow{2}{*}{ Root } & $-5 \mathrm{~cm}$ & 63.2 & 0.24 & -0.58 & 0.05 \\
\hline & $-15 \mathrm{~cm}$ & 5 & 155 & 1.93 & -0.42 & 0.03 & & $-15 \mathrm{~cm}$ & 111 & 0.40 & -0.59 & 0.06 \\
\hline Whole plant & & 91.96 & 87.20 & 70.65 & -0.65 & 0.23 & & & & & & \\
\hline
\end{tabular}


Table 5. Nickel isotopic fractionation $\Delta^{60} \mathrm{Ni}$, calculated between bulk soil and average $\delta^{60} \mathrm{Ni}$ in roots, $\Delta^{60} \mathrm{Ni}$ bulk -root, between available Ni and roots, $\Delta^{60} \mathrm{Ni}_{\text {available -root, }}$, and between roots and leaves, $\Delta^{60} \mathrm{Ni}_{\text {root-leaf. }}$. Reported $2 \sigma$ values were calculated applying the error propagation formulas reported in equation 4.

\begin{tabular}{|c|cc|cc|c|cc|}
\hline $\mathrm{SR}_{150}$ & $\Delta^{60} \mathrm{Ni}_{\text {bulk soil-root }}$ & $2 \sigma$ & $\Delta^{60} \mathrm{Ni}_{\text {available - root }}$ & $2 \sigma$ & Plant height & $\Delta^{60} \mathrm{Ni}_{\text {root-leaf }}$ & $2 \sigma$ \\
\hline $\mathrm{H} 1$ & 0.21 & 0.12 & 0.06 & 0.12 & $50 \mathrm{~cm}$ & 0.28 & 0.08 \\
$\mathrm{H} 2$ & 0.22 & 0.09 & 0.24 & 0.09 & $60 \mathrm{~cm}$ & 0.37 & 0.08 \\
& & & & & $80 \mathrm{~cm}$ & 0.40 & 0.08 \\
& & & & & $110 \mathrm{~cm}$ & 0.44 & 0.08 \\
& & & & & $150 \mathrm{~cm}$ & 0.51 & 0.07 \\
\hline $\mathrm{SR}_{600}$ & $\Delta^{60} \mathrm{Ni}_{\text {bulk -root }}$ & $2 \sigma$ & $\Delta^{60} \mathrm{Ni}_{\text {available - root }}$ & $2 \sigma$ & Plant height & $\Delta^{60} \mathrm{Ni}_{\text {root-leaf }}$ & $2 \sigma$ \\
\hline $\mathrm{H} 1$ & 0.58 & 0.08 & 0.91 & 0.09 & $2 \mathrm{~m}$ & -0.26 & 0.08 \\
$\mathrm{H} 2$ & 0.60 & 0.09 & 1.11 & 0.08 & $3 \mathrm{~m}$ & -0.40 & 0.08 \\
$\mathrm{H} 3$ & & & 1.21 & 0.07 & $4 \mathrm{~m}$ & -0.39 & 0.08 \\
& & & & & $5 \mathrm{~m}$ & -0.29 & 0.07 \\
& & & & & $6 \mathrm{~m}$ & -0.34 & 0.11 \\
\hline
\end{tabular}



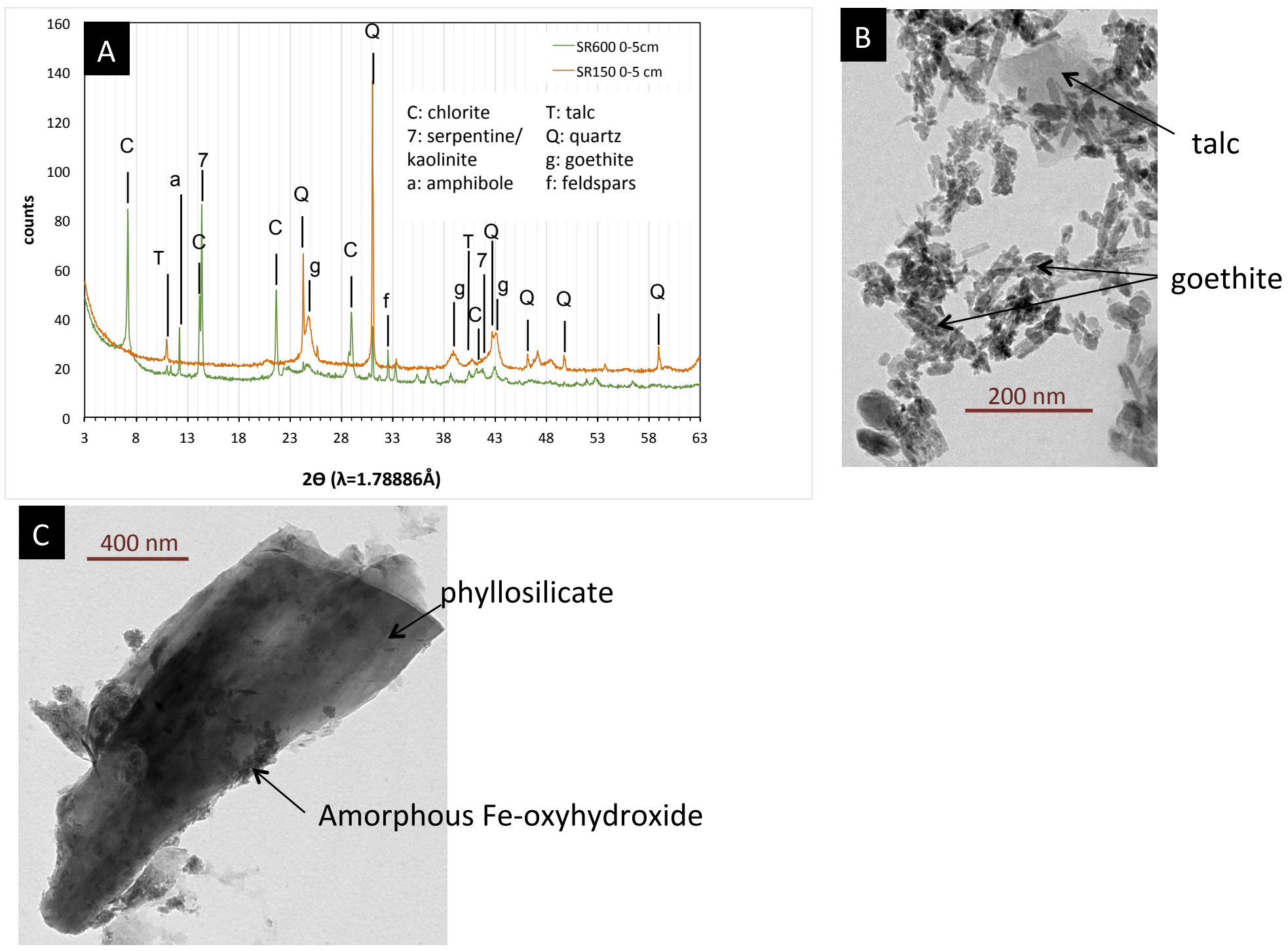

Fig.1 XRD patterns obtained on bulk soils, $\mathrm{H} 1$ horizons of $\mathrm{SR}_{150}$ and $\mathrm{SR}_{600}$ (A). TEM micrographs of the fine fraction $<50 \mu \mathrm{m}$ of $\mathrm{SR}_{150}(\mathrm{~B})$ and $\mathrm{SR}_{600}(\mathrm{C})$ soils, $\mathrm{H} 1$ horizons. 

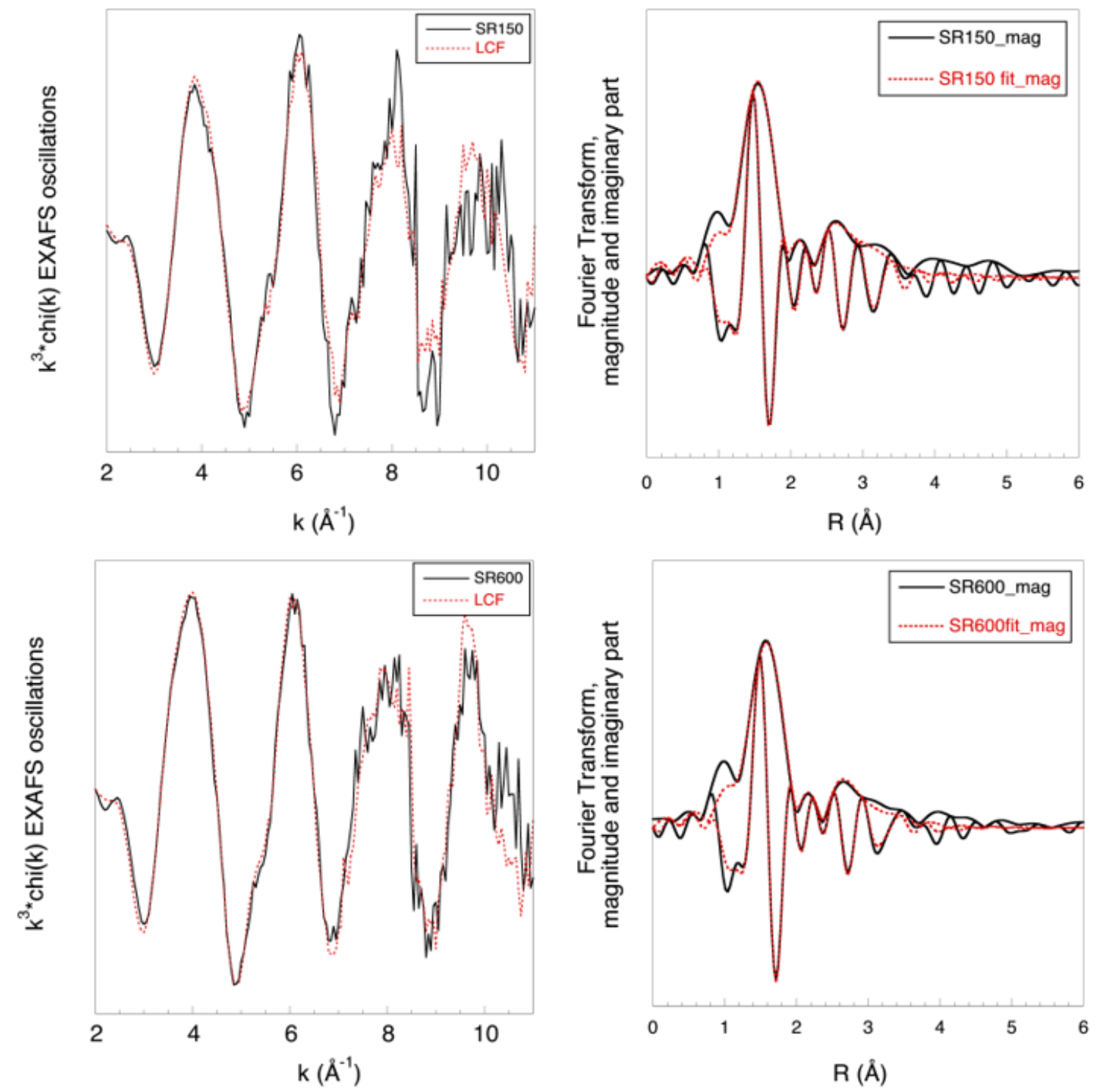

Fig.2 EXAFS oscillations obtained at Ni-K edge, Linear combination fitting (left graphs) and theoretical fitting (or shell by shell fitting, right graphs), for $\mathrm{SR}_{150}$ (up) and $\mathrm{SR}_{600}$ (down). Fitting parameters are reported in Table 2. 


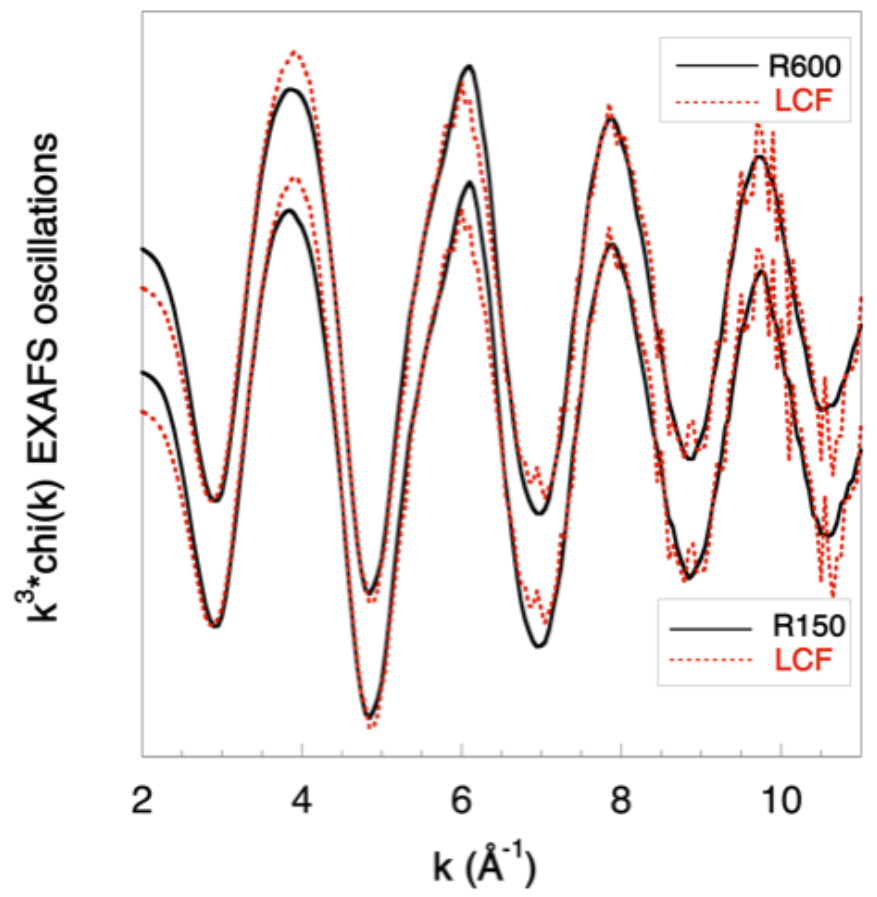

Fig.3 EXAFS oscillations at Ni K edge of R.cf. bengalensis leaves from $\mathrm{R}_{150}$ and $\mathrm{R}_{600}$ specimen. Oscillations are fitted as a combination of reference spectra (see Table 3 for fitting parameters). 

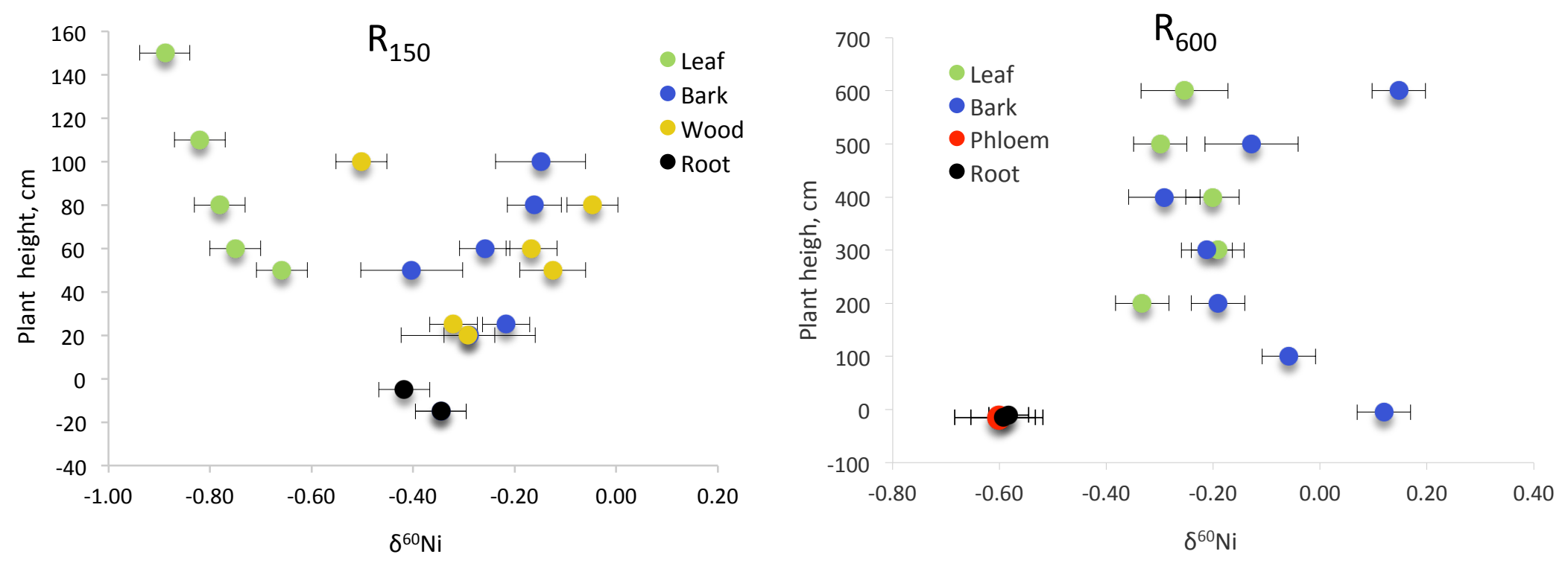

Fig.4 Nickel isotopic composition, $\delta^{60} \mathrm{Ni}$, in leaf, root, bark and wood samples of $R$. cf. bengalensis specimen $\mathrm{R}_{150}$, and in leaf, bark and phloem tissue samples of the $\mathrm{R}_{600}$ specimen. All results are the average of three measurements for each sample and the relative standard deviations correspond to the instrumental error. When the $2 \sigma$ associated to $\delta^{60} \mathrm{Ni}$ values are $<0.05 \%$, the value of $2 \sigma=0.05 \%$ obtained for Oak Leaves reference material V464 $\left(\delta^{60} \mathrm{Ni}=-0.02 \pm 0.05 \%, \mathrm{~N}=6\right)$ is used. 
Table SI 1. Elemental composition of $\mathrm{SR}_{150}$ and $\mathrm{SR}_{600}$ soil samples in $\mu \mathrm{mol} \mathrm{kg} \mathrm{kg}^{-1}$ for trace elements, oxide percentages for major elements and percentage of organic carbon. The range of standard deviation associated to reported results is between $5 \%$ and $20 \%$ for trace elements $(5 \%$ for $\mathrm{Ni}$ ), between $2 \%$ and $10 \%$ for major and minor elements, and $2 \%$ for organic carbon, as reported by the Service d'Analyse des Roches et des Minéraux, at Centre de Recherches Pétrographiques et Géochimiques, Nancy, France.

\begin{tabular}{|c|c|c|c|c|c|c|c|c|c|c|c|c|c|c|c|c|}
\hline$\mu \mathrm{mol} \mathrm{kg}{ }^{-1}$ and $\%$ & $\mathrm{Cu}$ & $\mathbf{P b}$ & Sc & Co & $\mathrm{Cr}$ & $\mathbf{Z n}$ & $\% \mathrm{SiO}_{2}$ & $\% \mathrm{Al}_{2} \mathrm{O}_{3}$ & $\% \mathrm{Fe}_{2} \mathrm{O}_{3}$ & $\% \mathrm{MnO}$ & $\% \mathrm{MgO}$ & $\% \mathrm{CaO}$ & $\% \mathrm{Na}_{2} \mathrm{O}$ & $\% \mathrm{~K}_{2} \mathrm{O}$ & $\% \mathrm{TiO}_{2}$ & $\% \mathrm{C}_{\text {org }}$ \\
\hline $\mathrm{SR}_{150} \mathrm{H} 1$ bulk & 591 & 24.71 & 663 & 7.46 & 283 & 3.59 & 28.9 & 4.36 & 34.0 & 0.47 & 1.43 & 0.49 & $<$ d.l. & 0.10 & 0.15 & 7.44 \\
\hline $\mathrm{SR}_{150} \mathrm{H} 2$ bulk & 556 & 23.36 & 773 & 8.89 & 364 & 3.66 & 30.5 & 5.15 & 39.8 & 0.52 & 1.61 & 0.14 & $<$ d.l. & 0.07 & 0.18 & 2.91 \\
\hline $\mathrm{SR}_{150} \mathrm{H} 1>1.5 \mathrm{~mm}$ & 517 & 24.07 & 686 & 7.67 & 302 & 3.62 & 30.2 & 4.53 & 35.1 & 0.48 & 1.46 & 0.41 & $<$ d.l. & 0.09 & 0.16 & / \\
\hline $\mathrm{SR}_{150} \mathrm{H} 1250-50 \mu \mathrm{m}$ & 818 & 33.18 & 630 & 6.91 & 313 & 3.80 & 26.7 & 4.20 & 31.5 & 0.43 & 1.42 & 0.62 & $<$ d.l. & 0.10 & 0.14 & / \\
\hline $\mathrm{SR}_{150} \mathrm{H} 1<50 \mu \mathrm{m}$ & 1037 & 24.40 & 598 & 5.46 & 206 & 3.36 & 34.6 & 3.80 & 29.9 & 0.35 & 1.16 & 0.55 & $<$ d.l. & 0.10 & 0.14 & / \\
\hline $\mathrm{SR}_{600} \mathrm{H} 1$ bulk & 573 & 12.79 & 424 & 4.65 & 276 & 3.95 & 29.2 & 4.96 & 14.6 & 0.35 & 10.77 & 1.06 & 0.21 & 0.04 & 0.20 & 11.84 \\
\hline $\mathrm{SR}_{600} \mathrm{H} 2$ bulk & 510 & 13.48 & 566 & 6.74 & 358 & 4.89 & 36.9 & 6.58 & 19.3 & 0.51 & 13.21 & 1.09 & 0.28 & $<$ d.1. & 0.24 & 3.01 \\
\hline $\mathrm{SR}_{600} \mathrm{H} 3$ bulk & 548 & 13.70 & 596 & 8.39 & 381 & 4.70 & 35.4 & 7.02 & 22.1 & 0.64 & 13.41 & 0.97 & 0.29 & $<$ d.1. & 0.23 & 1.64 \\
\hline $\mathrm{SR}_{600} \mathrm{H} 1>1.5 \mathrm{~mm}$ & 586 & 11.57 & 463 & 6.12 & 296 & 3.83 & 31.2 & 5.40 & 16.3 & 0.49 & 11.48 & 1.03 & 0.21 & 0.04 & 0.20 & / \\
\hline $\mathrm{SR}_{600} \mathrm{H} 1250-50 \mu \mathrm{m}$ & 902 & 28.74 & 370 & 2.97 & 245 & 3.32 & 26.5 & 4.40 & 11.3 & 0.24 & 9.61 & 1.26 & 0.22 & 0.05 & 0.20 & l \\
\hline $\mathrm{SR}_{600} \mathrm{H} 1<50 \mu \mathrm{m}$ & 1695 & 41.18 & 380 & 2.84 & 278 & 3.82 & 35.8 & 4.55 & 10.8 & 0.24 & 10.25 & 1.33 & 0.28 & 0.06 & 0.16 & I \\
\hline
\end{tabular}

$<$ d.1. $=$ below the limit of detection 
Table SI 2. Exchangeable cations and total soil cation exchange capacity (CEC mEq per $100 \mathrm{~g}$ of soil), determined in bulk samples of different horizons of $\mathrm{SR}_{150}$ and $\mathrm{SR}_{600}$.

\begin{tabular}{|c|cccccccc|c|}
\hline Soil horizon & $\mathrm{Na}^{+}$ & $\mathrm{K}^{+}$ & $\mathrm{Ca}^{2+}$ & $\mathrm{Mg}^{2+}$ & $\mathrm{Fe}^{3+}$ & $\mathrm{Al}^{3+}$ & $\mathrm{Si}^{4+}$ & $\mathrm{Ni}^{2+}$ & $\begin{array}{c}\text { Total } \\
\text { CEC }\end{array}$ \\
\hline $\mathrm{SR}_{150} \mathrm{H} 1$ & 0.08 & 0.79 & 14.4 & 5.8 & $<$ d.l. & $<$ d.1. & 1.24 & 0.30 & 22.7 \\
$\mathrm{SR}_{150} \mathrm{H} 2$ & 0.03 & 0.24 & 3.66 & 2.08 & $<$ d.l. & 0.07 & 1.15 & 0.49 & 7.72 \\
\hline $\mathrm{SR}_{600} \mathrm{H} 1$ & 0.09 & 0.59 & 10.0 & 42.4 & $<$ d.l. & $<$ d.1. & 1.09 & 0.38 & 54.6 \\
$\mathrm{SR}_{600} \mathrm{H} 2$ & 0.05 & 0.17 & 3.22 & 20.1 & $<$ d.1. & $<$ d.1. & 1.15 & 0.23 & 24.9 \\
$\mathrm{SR}_{600} \mathrm{H} 3$ & 0.05 & 0.06 & 1.21 & 16.1 & $<$ d.1. & 0.05 & 1.17 & 0.12 & 18.7 \\
\hline
\end{tabular}

$<$ d.1. = below the limit of detection 
Table SI 3. Element concentrations $\left(\mu \mathrm{mol} \mathrm{g} \mathrm{g}^{-1}\right.$ ) in leaf, bark, wood and root samples of $R$. bengalensis $\mathrm{R}_{150}$ plant. Results are the average of three measurements for each samples. Standard deviation correspond to the triplicate of the measurements.

\begin{tabular}{|c|c|c|c|c|c|c|c|c|c|c|c|}
\hline $\begin{array}{l}\text { Tree } \\
\text { part }\end{array}$ & Height & $\mathrm{Mg}$ & K & $\mathrm{Ca}$ & $\mathrm{Mn}$ & $\mathrm{Fe}$ & $\mathrm{Ni}$ & $\mathrm{Zn}$ & $\mathrm{Cr}$ & $\mathrm{Cu}$ & $\mathrm{Co}$ \\
\hline \multirow{5}{*}{ Leaf } & $50 \mathrm{~cm}$ & $132 \pm 0.9$ & $483 \pm 3.8$ & $749 \pm 22.4$ & $12.7 \pm 0.14$ & $10.6 \pm 0.16$ & $171 \pm 1.10$ & $2.56 \pm 0.01$ & $0.1 \pm 0.01$ & $0.07 \pm 0.01$ & $1.78 \pm 0.03$ \\
\hline & $60 \mathrm{~cm}$ & $131 \pm 0.24$ & $459 \pm 2.0$ & $785 \pm 21.3$ & $12.5 \pm 0.06$ & $13.3 \pm 13.6$ & $156 \pm 0.62$ & $2.83 \pm 0.03$ & $0.2 \pm 0.01$ & $0.07 \pm 0.01$ & $1.74 \pm 0.01$ \\
\hline & $80 \mathrm{~cm}$ & $85 \pm 0.73$ & $516 \pm 1.4$ & $621 \pm 19.7$ & $10.1 \pm 0.02$ & $8.37 \pm 0.37$ & $221 \pm 16.0$ & $6.73 \pm 0.07$ & $0.1 \pm 0.01$ & $0.06 \pm 0.01$ & $1.59 \pm 0.01$ \\
\hline & $110 \mathrm{~cm}$ & $139 \pm 0.60$ & $366 \pm 3.5$ & $691 \pm 22$ & $14.8 \pm 0.12$ & $10.6 \pm 0.85$ & $134 \pm 2.40$ & $3.03 \pm 0.05$ & $0.1 \pm 0.01$ & $0.09 \pm 0.01$ & $1.68 \pm 0.03$ \\
\hline & $150 \mathrm{~cm}$ & $172 \pm 1.78$ & $546 \pm 6.3$ & $651 \pm 31.0$ & $14.8 \pm 0.31$ & $9.08 \pm 1.85$ & $138 \pm 2.75$ & $3.61 \pm 0.05$ & $0.1 \pm 0.01$ & $0.09 \pm 0.01$ & $1.47 \pm 0.04$ \\
\hline & & & & & & & & & & & \\
\hline \multirow{6}{*}{ Bark } & $20 \mathrm{~cm}$ & $41.5 \pm 0.17$ & $244 \pm 1.2$ & $1697 \pm 38.4$ & $2.0 \pm 0.03$ & $19.9 \pm 1.16$ & $68.7 \pm 0.78$ & $6.76 \pm 0.10$ & $0.2 \pm 0.01$ & $0.06 \pm 0.01$ & $0.18 \pm 0.0$ \\
\hline & $25 \mathrm{~cm}$ & $41.1 \pm 0.12$ & $203 \pm 1.2$ & $2093 \pm 10.4$ & $2.3 \pm 0.01$ & $27.2 \pm 0.83$ & $62.1 \pm 0.49$ & $7.42 \pm 0.06$ & $0.2 \pm 0.0$ & $0.09 \pm 0.0$ & $0.19 \pm 0.0$ \\
\hline & $40 \mathrm{~cm}$ & $62.9 \pm 0.13$ & $221 \pm 2.4$ & $1669 \pm 41.6$ & $4.4 \pm 0.06$ & $17.6 \pm 1.48$ & $58 \pm 0.37$ & $3.54 \pm 0.07$ & $0.0 \pm 0.0$ & $0.11 \pm 0.01$ & $0.27 \pm 0.01$ \\
\hline & $60 \mathrm{~cm}$ & $46.1 \pm 0.26$ & $243 \pm 1.0$ & $1519 \pm 32.4$ & $5.4 \pm 0.06$ & $14.5 \pm 1.24$ & $43.0 \pm 0.46$ & $2.38 \pm 0.01$ & 0.0 & $0.12 \pm 0.01$ & $0.24 \pm 0.01$ \\
\hline & $80 \mathrm{~cm}$ & $71.2 \pm 0.03$ & $344 \pm 3.3$ & $1404 \pm 48.6$ & $3.0 \pm 0.04$ & $18 \pm 2.15$ & $67.5 \pm 1.07$ & $3.69 \pm 0.07$ & $0.7 \pm 0.64$ & $0.15 \pm 0.01$ & $0.23 \pm 0.01$ \\
\hline & $90 \mathrm{~cm}$ & $107 \pm 1.28$ & $507 \pm 2.3$ & $1364 \pm 25.4$ & $2.01 \pm 0.02$ & $15.5 \pm 1.42$ & $98.6 \pm 0.73$ & $4.43 \pm 0.01$ & $0.0 \pm 0$ & $0.13 \pm 0.73$ & $0.3 \pm 0.01$ \\
\hline & & & & & & & & & & & \\
\hline \multirow{6}{*}{ Wood } & $20 \mathrm{~cm}$ & $22.6 \pm 0.15$ & $128 \pm 2.0$ & $333 \pm 20.9$ & $0.2 \pm 0.01$ & $4.47 \pm 0.58$ & $6.7 \pm 0.04$ & 0.25 & $<$ d.1. & $0.02 \pm 0$ & $0.02 \pm 0.0$ \\
\hline & $25 \mathrm{~cm}$ & $22.9 \pm 0.13$ & $154 \pm 2.8$ & $454 \pm 26.1$ & $0.3 \pm 0.01$ & $7.48 \pm 0.62$ & $9.4 \pm 0.12$ & $0.36 \pm 0.01$ & $<$ d.1. & $0.05 \pm 0.01$ & $0.03 \pm 0$ \\
\hline & $40 \mathrm{~cm}$ & $34.4 \pm 0.08$ & $224 \pm 37.3$ & $666 \pm 32.9$ & $0.4 \pm 0.02$ & $8.96 \pm 1.02$ & $15.6 \pm 0.15$ & $0.59 \pm 0.01$ & $<$ d.1. & $0.08 \pm 0.01$ & $0.05 \pm 0$ \\
\hline & $60 \mathrm{~cm}$ & $36.1 \pm 0.37$ & $205 \pm 3.2$ & $673 \pm 20.2$ & $0.4 \pm 0.01$ & $8.14 \pm 0.80$ & $11.9 \pm 0.11$ & $0.89 \pm 0.02$ & $<$ d.l. & $0.04 \pm 0.01$ & $0.04 \pm 0$ \\
\hline & $80 \mathrm{~cm}$ & $47.9 \pm 0.66$ & $305 \pm 1.7$ & $623 \pm 18.3$ & $0.5 \pm 0.01$ & $8.16 \pm 0.86$ & $28.1 \pm 0.38$ & $0.88 \pm 0.01$ & $<$ d.1. & $0.20 \pm 0.02$ & $0.07 \pm 0.0$ \\
\hline & $100 \mathrm{~cm}$ & $65.7 \pm 0.30$ & $412 \pm 3.3$ & $629 \pm 34.1$ & $0.8 \pm 0.02$ & $10.0 \pm 1.08$ & $69.9 \pm 0.62$ & $1.67 \pm 0.02$ & $<$ d.l. & $0.20 \pm 0.02$ & $0.16 \pm 0.0$ \\
\hline \multirow[b]{2}{*}{ Root } & & $1+125$ & & & & & & & & & \\
\hline & $-15 \mathrm{~cm}$ & $85.7 \pm 0.66$ & $\begin{array}{l}25 / \pm 2.1 \\
155 \pm 1.4\end{array}$ & $414 \pm 16.4$ & $3.2 \pm 0.05$ & $169 \pm 2.78$ & $81.7 \pm 0.95$ & $\frac{2.0 / \pm 0.03}{2.37 \pm 0.02}$ & $4.1 \pm 0.35$ & $\begin{array}{l}0.00 \pm 0.0 \\
0.07 \pm 0.0\end{array}$ & $0.38 \pm 0.0$ \\
\hline
\end{tabular}

$<$ d.l. $=$ below the limit of detection 
Table SI 4. Element concentrations ( $\mu \mathrm{mol} \mathrm{g}{ }^{-1}$ ) in leaf, bark, and phloem samples of $R$. bengalensis $\mathrm{R}_{600}$ plant. Results are the average of three measurements for each samples. Standard deviation correspond to the triplicate of the measurements.

\begin{tabular}{|c|c|c|c|c|c|c|c|c|c|c|c|}
\hline $\begin{array}{l}\text { Tree } \\
\text { part }\end{array}$ & Height & $\mathrm{Mg}$ & K & $\mathrm{Ca}$ & $\mathrm{Mn}$ & $\mathrm{Fe}$ & $\mathrm{Ni}$ & $\mathrm{Zn}$ & $\mathrm{Cr}$ & $\mathrm{Cu}$ & $\mathrm{Co}$ \\
\hline \multirow{5}{*}{ Leaf } & $2 \mathrm{~m}$ & $149 \pm 0.75$ & $684 \pm 10.7$ & $995 \pm 36.8$ & $1.98 \pm 0.03$ & $9.99 \pm 1.18$ & $522 \pm 7.83$ & $3.76 \pm 0$ & $0.06 \pm 0.01$ & $0.05 \pm 0.01$ & $0.32 \pm 0.01$ \\
\hline & $3 m$ & $183 \pm 1.42$ & $463 \pm 3.37$ & $923 \pm 22.1$ & $1.83 \pm 0.02$ & $8.93 \pm 0.44$ & $349 \pm 5.50$ & $2.15 \pm 0$ & $0.09 \pm 0.01$ & $0.05 \pm 0.0$ & $0.19 \pm 0.01$ \\
\hline & $4 m$ & $144 \pm 1.77$ & $552 \pm 13.7$ & $854 \pm 28.3$ & $1.86 \pm 0.03$ & $8.95 \pm 0.80$ & $309 \pm 5.94$ & $1.31 \pm 0.01$ & $0.07 \pm 0.00$ & $0.06 \pm 0.0$ & $0.20 \pm 0.0$ \\
\hline & $5 \mathrm{~m}$ & $209 \pm 3.22$ & $686 \pm 21.5$ & $1180 \pm 221$ & $1.86 \pm 0.11$ & $20.2 \pm 7.51$ & $220 \pm 6.85$ & $2.13 \pm 0.01$ & $0.21 \pm 0.15$ & $<\mathrm{d} .1$ & $0.12 \pm 0.02$ \\
\hline & $6 \mathrm{~m}$ & $97 \pm 0.93$ & $436 \pm 26.5$ & $873 \pm 151$ & $2.15 \pm 0.02$ & $13.7 \pm 2.02$ & $156 \pm 1.17$ & $1.15 \pm 0.01$ & $0.21 \pm 0.05$ & $<$ d.1. & $0.17 \pm 0.01$ \\
\hline & & & & & & & & & & & \\
\hline \multirow{6}{*}{ Bark } & $1 \mathrm{~m}$ & $36 \pm 0.22$ & $278 \pm 3.95$ & $1565 \pm 35.7$ & $0.53 \pm 0.01$ & $14.2 \pm 0.45$ & $133 \pm 1.23$ & $1.94 \pm 0.0$ & $0.02 \pm 0.00$ & $0.06 \pm 0.01$ & $0.03 \pm 0$ \\
\hline & $2 \mathrm{~m}$ & $33 \pm 0.37$ & $305 \pm 4.98$ & $1544 \pm 25.2$ & $0.66 \pm 0.02$ & $14.1 \pm 0.68$ & $149 \pm 2.37$ & $1.60 \pm 0.0$ & $0.02 \pm 0.0$ & $0.05 \pm 0.01$ & $0.04 \pm 0$ \\
\hline & $3 \mathrm{~m}$ & $33 \pm 0.18$ & $287 \pm 4.81$ & $1486 \pm 35.1$ & $0.71 \pm 0.01$ & $14.2 \pm 1.42$ & $108 \pm 1.13$ & $0.66 \pm 0.0$ & $0.01 \pm 0.0$ & $0.07 \pm 0.01$ & $0.04 \pm 0$ \\
\hline & $4 m$ & $33 \pm 0.37$ & $450 \pm 4.62$ & $1553 \pm 14.8$ & $1.49 \pm 0.01$ & $14.0 \pm 0.5$ & $105 \pm 1.49$ & $0.87 \pm 0.0$ & $0.01 \pm 0.0$ & $0.07 \pm 0.0$ & $0.08 \pm 0$ \\
\hline & $5 \mathrm{~m}$ & $50 \pm 0.47$ & $293 \pm 6.26$ & $1770 \pm 39.2$ & $2.21 \pm 0.02$ & $16.4 \pm 0.9$ & $93 \pm 0.96$ & $1.40 \pm 0.0$ & $0.01 \pm 0.0$ & $0.08 \pm 0.0$ & $0.10 \pm 0$ \\
\hline & $6 \mathrm{~m}$ & $78 \pm 0.30$ & $155 \pm 1.22$ & $742 \pm 23.3$ & $0.49 \pm 0.0$ & $6.8 \pm 0.5$ & $53 \pm 0.38$ & $0.78 \pm 0.0$ & $0.01 \pm 0.0$ & $0.03 \pm 0.02$ & $0.02 \pm 0$ \\
\hline & & & & & & & & & & & \\
\hline \multirow{2}{*}{ Phloem } & $-5 \mathrm{~cm}$ & $127.1 \pm 0.74$ & $510 \pm 5.22$ & $1488 \pm 35.1$ & $10.6 \pm 0.09$ & $16.33 \pm 1.09$ & $545 \pm 7.05$ & $19.4 \pm 0.02$ & $0.26 \pm 0.01$ & $0 \pm 0$ & $0.6 \pm 0$ \\
\hline & $5 \mathrm{~m}$ & $71 \pm 0.76$ & $344 \pm 10.4$ & $580 \pm 79.0$ & $0.39 \pm 0.04$ & $3.50 \pm 2.97$ & $12 \pm 0.24$ & $0.09 \pm 0.00$ & $0.01 \pm 0.01$ & $0.07 \pm 0.03$ & $0.02 \pm 0$ \\
\hline \multirow{3}{*}{ Root } & & & & & & & & & & & \\
\hline & $-5 \mathrm{~cm}$ & $91.2 \pm 1.09$ & $228 \pm 3.40$ & $301 \pm 12.9$ & $1.37 \pm 0.01$ & $22.3 \pm 0.38$ & $63.2 \pm 0.24$ & $3.03 \pm 0.01$ & $1.50 \pm 0.07$ & $0.11 \pm 0.0$ & $0.09 \pm 0$ \\
\hline & $-15 \mathrm{~cm}$ & $186 \pm 0.61$ & $188 \pm 10.4$ & $447 \pm 232$ & $2.60 \pm 0.08$ & $41.9 \pm 8.77$ & $111 \pm 0.4$ & $5.57 \pm 0.00$ & $4.35 \pm 0.07$ & $0.22 \pm 0.08$ & $0.17 \pm 0.01$ \\
\hline
\end{tabular}

$<$ d.1. = below the limit of detection 


\section{Notes}

The concentrations of $\mathrm{Ca}$ and $\mathrm{K}$ in the plant material are relatively high compared to the amount of exchangeable cations in the corresponding soils. In both plants, the highest Ca concentration is in the bark, where it reaches $2000 \mu \mathrm{mol} \mathrm{g}^{-1}$ and $1700 \mu \mathrm{mol} \mathrm{g}^{-1}$ in $\mathrm{R}_{150}$ and $\mathrm{R}_{600}$, respectively. The highest $\mathrm{K}$ concentrations is recorded in the leaves, $546 \mu \mathrm{mol} \mathrm{g}{ }^{-1}$ in $\mathrm{R}_{150}$ and $686 \mu \mathrm{mol} \mathrm{g}{ }^{-1} \mathrm{R}_{600}$. Despite the fact that exchangeable $\mathrm{Mg}$ in the soil is 10 -fold higher in $\mathrm{SR}_{600}$ than in $\mathrm{SR}_{150}$, $\mathrm{Mg}$ concentrations are similar in both plants, e.g. $\sim 150 \mu \mathrm{mol} \mathrm{g}^{-1}$ in the leaves. Other elemental concentrations, such as $\mathrm{Fe}, \mathrm{Mn}, \mathrm{Cu}$ and $\mathrm{Zn}$ are in the ranges previously reported for R. bengalensis(van der Ent et al., 2017).

Some clear trends are found in $\mathrm{R}_{150}$, the $\mathrm{Mg}$ and $\mathrm{K}$ concentrations in the bark and wood increase with height, from the bottom to the top. This trend is also observed for $\mathrm{Mg}$ in bark of $\mathrm{R}_{600}$, but no trend is observed for $\mathrm{K}$. For the trace elements no clear trends is found. Cobalt is more concentrated in $\mathrm{R}_{150}$ leaves than in $\mathrm{R}_{600}$ leaves, although Co contents in $\mathrm{SR}_{150}$ and $\mathrm{SR}_{600}$ soils are in the same range of order. 


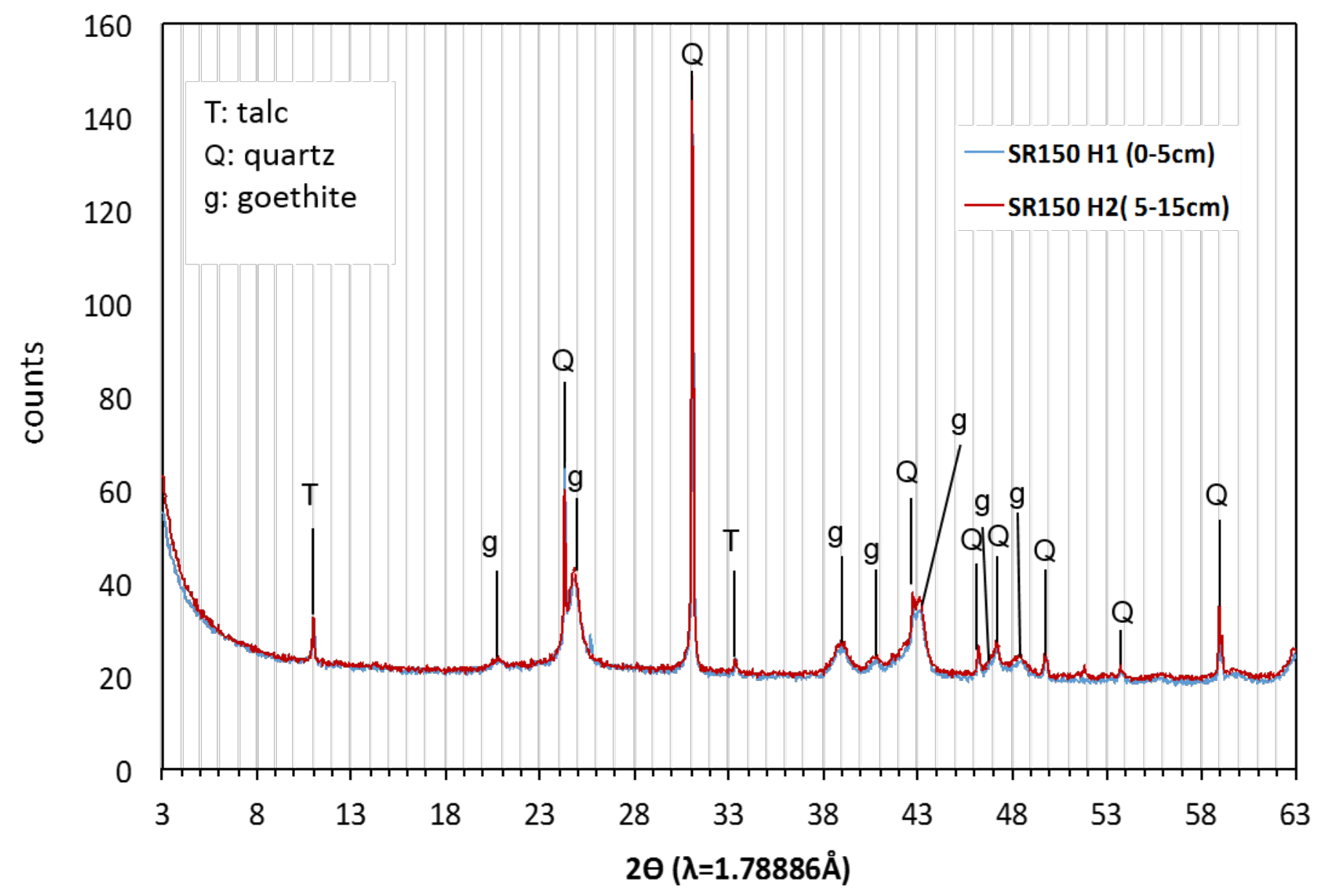

Figure SI 1. XRD patterns obtained on $\mathrm{SR}_{150}$ bulk soil, horizon $\mathrm{H} 1(0-5 \mathrm{~cm})$ and $\mathrm{H} 2(5-15 \mathrm{~cm})$. The pattern demonstrates the predominance of goethite and quartz, associated to one phyllosilicate (talc), no clay minerals or other silicate could be evidenced. 


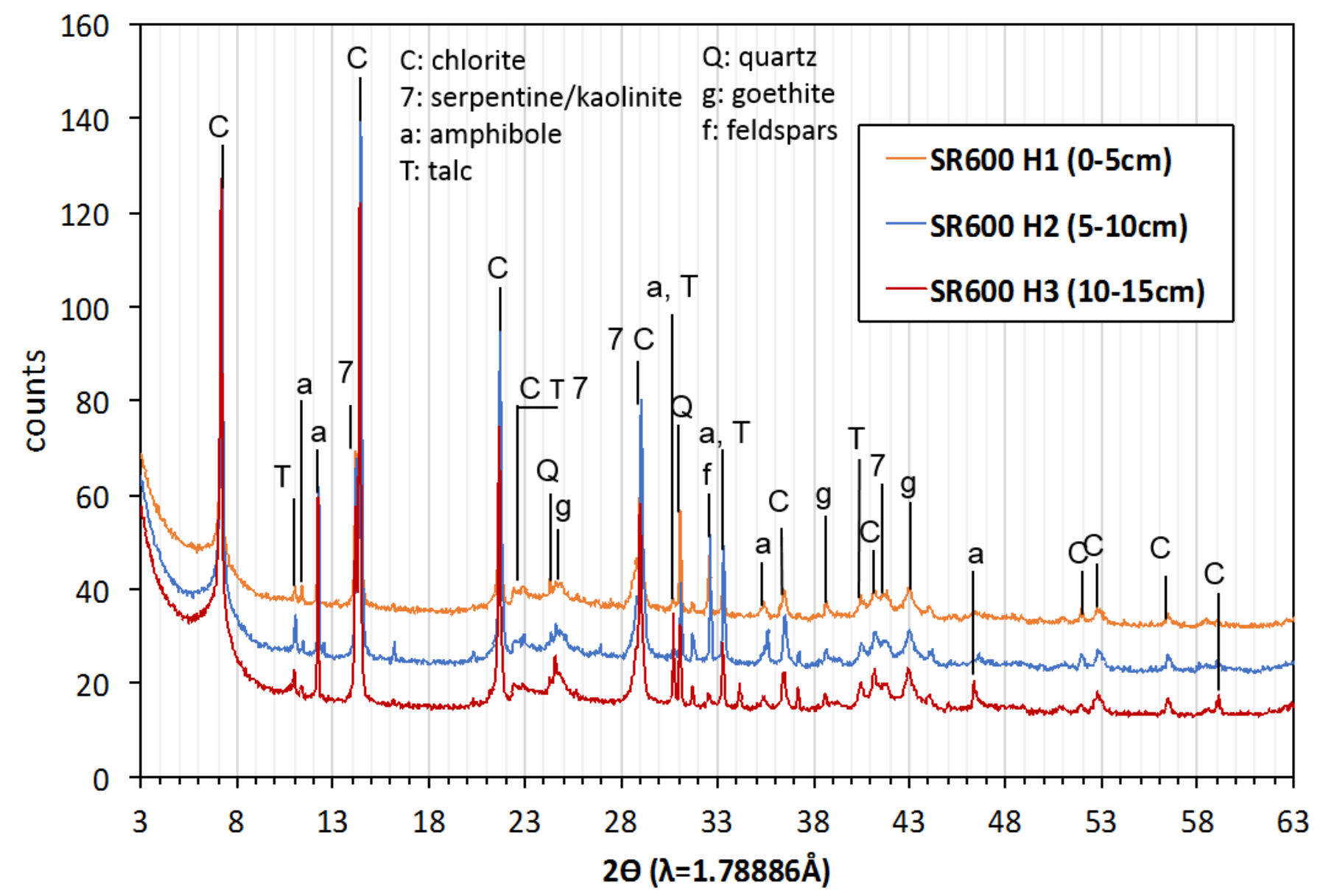

Figure SI 2. XRD patterns obtained on $\mathrm{SR}_{600}$ bulk soil, horizon $\mathrm{H} 1(0-5 \mathrm{~cm}), \mathrm{H} 2(5-10 \mathrm{~cm})$ and $\mathrm{H} 3(10-15 \mathrm{~cm})$. The patterns evidence a predominance of phyllosilicates, chlorite, talc and $7 \AA$ phyllosilicate (serpentine or kaolinite). Primary minerals such as amphibole and feldspars were also detected. Quartz and goethite appear as minor phases. 


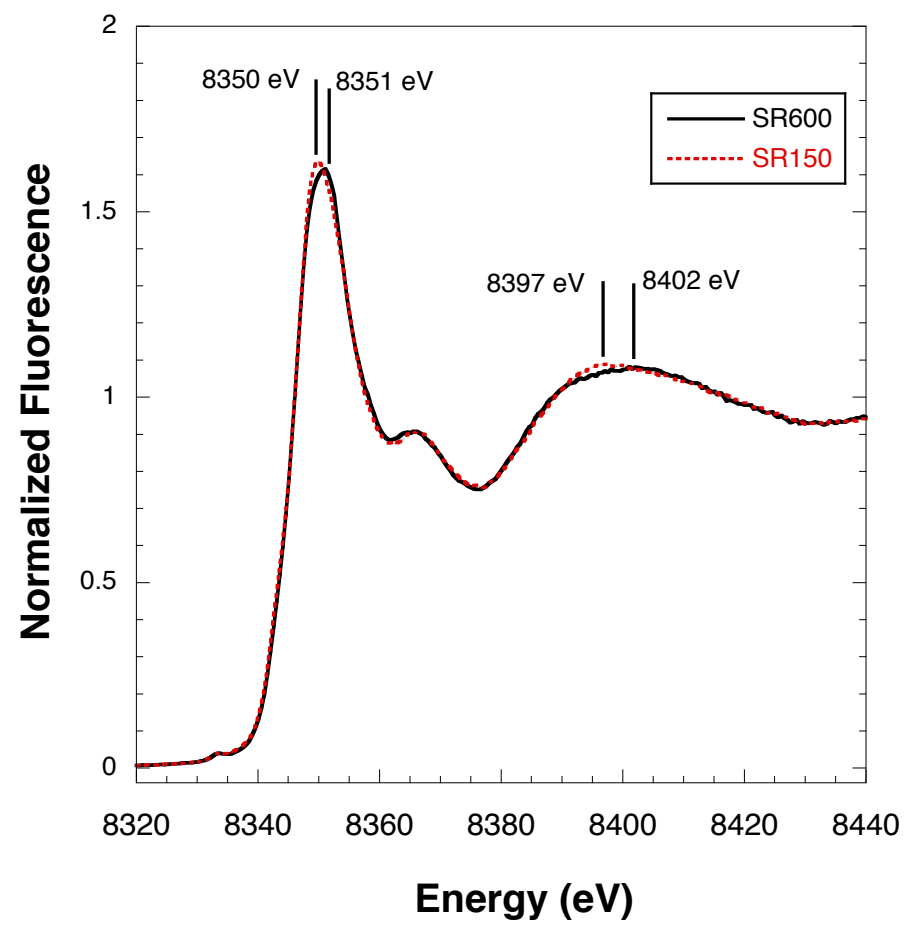

Figure SI 3. XANES spectra at Ni-K edge from $\mathrm{SR}_{150}$ and $\mathrm{SR}_{600}$ soils (surface horizon $\mathrm{H} 1$, bulk soil samples). 


\section{References}

van der Ent, A., Callahan, D. L., Noller, B. N., Mesjasz-Przybylowicz, J., Przybylowicz, W., Barnabas, A., \& Harris, H. H. (2017). Nickel biopathways in tropical nickel hyperaccumulating trees from Sabah (Malaysia). Scientific Reports, 7. https://doi.org/DOI: 10.1038/srep41861 